University of Wollongong

Research Online

Faculty of Engineering and Information

Faculty of Engineering and Information

Sciences - Papers: Part A

Sciences

$1-1-2016$

Incorporating environmental evaluation and thermal properties of concrete mix designs

Mehdi Robati

University of Wollongong, mr329@uowmail.edu.au

Timothy J. McCarthy

University of Wollongong, timmc@uow.edu.au

Georgios Kokogiannakis

University of Wollongong, gkg@uow.edu.au

Follow this and additional works at: https://ro.uow.edu.au/eispapers

Part of the Engineering Commons, and the Science and Technology Studies Commons

Research Online is the open access institutional repository for the University of Wollongong. For further information contact the UOW Library: research-pubs@uow.edu.au 


\title{
Incorporating environmental evaluation and thermal properties of concrete mix designs
}

\begin{abstract}
One of the main challenges in sustainable design of buildings is to improve the energy efficiency of the building during its lifetime along with reducing the environmental impact of the design. Recent advances in concrete technology offer lower embodied emission through the application of supplementary cementitious materials and recycled aggregates. There are also improvements to thermal properties with the application of admixtures. However, the relationships between the environmental impact (Cradle to Gate) and thermal performance of concrete mix designs have not been researched adequately. The Green House Gas (GHG) emissions associated with each individual concrete component and its production need to be considered with greater refinement. This study correlates the impacts of selecting a concrete mix design in terms of $\mathrm{CO}_{2}$-e with resulting thermal conductivity and density at the design stage of buildings. This paper examines 90 concrete mix designs from published literature to identify their embodied emissions and thermal conductivity in order to discuss the relationship between low embodied carbon dioxide equivalents $\left(\mathrm{CO}_{2}-\mathrm{e}\right)$ emission alternatives and thermal conductivity. The embodied $\mathrm{CO}_{2}-\mathrm{e}$ of a variety concrete mix designs were quantified by compiling embodied $\mathrm{CO}_{2}$-e coefficient for each individual component in the concrete. The results show the variation in embodied CO2-e and thermal conductivity of concrete mixes. The application of readily available supplementary cementitious material can reduce embodied $\mathrm{CO}_{2}-\mathrm{e}\left(\mathrm{kg} \mathrm{CO}_{2}-\mathrm{e}\right)$ by up to $16 \%$ in comparison with general practice. Furthermore, the thermal conductivity of concrete mix is influenced by changing the density of aggregates and the proportion of cementitious materials. In completing this work the results obtained from the study are compared with six different inventory databases: ICE (Hammond et al., 2011), Crawford (2011), Alcon (2003), eTool (2014), BPIC (2014) and AusLCI (2013). The comparison identifies some inconsistencies in calculation of embodied $\mathrm{CO}_{2}$-e across the different databases. This is attributed to variation in embodied $\mathrm{CO}_{2}$-e coefficients and lack of in-depth consideration of the detailed properties of each individual concrete mix design.
\end{abstract}

\section{Keywords}

mix, concrete, designs, properties, environmental, evaluation, thermal, incorporating

\section{Disciplines}

Engineering | Science and Technology Studies

\section{Publication Details}

Robati, M., McCarthy, T. J. \& Kokogiannakis, G. (2016). Incorporating environmental evaluation and thermal properties of concrete mix designs. Construction and Building Materials, 128 422-435. 


\title{
Incorporating environmental evaluation and thermal properties of concrete mix designs
}

\author{
Mehdi Robati ${ }^{* 1,2}$, Timothy J McCarthy ${ }^{1}$, Georgios Kokogiannakis ${ }^{2}$ \\ ${ }^{1}$ School of Civil, Mining and Environment, Faculty of Engineering and Information Sciences, University of \\ Wollongong, Australia \\ ${ }^{2}$ Sustainable Buildings Research Centre (SBRC), University of Wollongong, Australia \\ *Corresponding author. Tel.: +61 420477662. \\ E-mail address: mr329@uowmail.edu.au (Mehdi Robati)
}

\begin{abstract}
One of the main challenges in sustainable design of buildings is to improve the energy efficiency of the building during its lifetime along with reducing the environmental impact of the design. Recent advances in concrete technology offer lower embodied emission through the application of supplementary cementitious materials and recycled aggregates. There are also improvements to thermal properties with the application of admixtures. However, the relationships between the environmental impact (Cradle to Gate) and thermal performance of concrete mix designs have not been researched adequately. The Green House Gas (GHG) emissions associated with each individual concrete component and its production need to be considered with greater refinement. This study correlates the impacts of selecting a concrete mix design in terms of $\mathrm{CO} 2$-e with resulting thermal conductivity and density at the design stage of buildings. This paper examines 90 concrete mix designs from published literature to identify their embodied emissions and thermal conductivity in order to discuss the relationship between low embodied carbon dioxide equivalents $\left(\mathrm{CO}_{2}\right.$-e $)$ emission alternatives and thermal conductivity. The embodied $\mathrm{CO}_{2}$-e of a variety concrete mix designs were quantified by compiling embodied $\mathrm{CO}_{2}$-e coefficient for each individual component in the concrete. The results show the variation in embodied $\mathrm{CO}_{2}$-e and thermal conductivity of concrete mixes. The application of readily available supplementary cementitious material can reduce embodied $\mathrm{CO}_{2}-\mathrm{e}(\mathrm{kg}$ $\mathrm{CO}_{2}$-e) by up to $16 \%$ in comparison with general practice. Furthermore, the thermal conductivity of concrete mix is influenced by changing the density of aggregates and the proportion of cementitious materials. In completing this work the results obtained from the study are compared with six different inventory databases: ICE [1], Crawford [2], Alcon [3], eTool [4], BPIC [5] and AusLCI [6]. The comparison identifies some inconsistencies in calculation of embodied $\mathrm{CO}_{2}$-e across the different databases. This is attributed to variation in embodied $\mathrm{CO}_{2}$-e coefficients and lack of in-depth consideration of the detailed properties of each individual concrete mix design.
\end{abstract}

Keyword: Concrete mix design, Embodied emission, Thermal conductivity, GHG, $\mathrm{CO}_{2}-\mathrm{e}$ 


\section{1-Introduction}

Concrete is the most widely used construction material in the building industry and consumes the second highest amount of natural resources [7]. The main constituents of general purpose concrete are cement, water and aggregates. The most carbon intensive components in manufacturing concrete are cement and aggregates. A report released by the United States Geological Survey shows that global cement production increased by 100 million tonnes in one year to a total of 4.18 billion tonne in 2014 [8]. The American Portland Cement Association (PCA) has estimated this cement consumption trend will continue to increase into the future [9].

Concrete is a popular material because it has excellent mechanical and durability properties. It is adaptable, relatively fire resistant and generally available and affordable. Concrete has the ability to absorb and retain energy for a considerable period of time. This action reduces energy consumption by transferring heat in a natural daily cycle through the structural components (thermal mass) of the building. The mass components reduce the temperature fluctuations in building spaces and can therefore reduce the associated peak heating or cooling loads [10].

Through its high thermal mass, a concrete slab can often absorb heat during the day and release it back to the room at night. The relatively high specific heat of solid concrete makes it attractive as a passive thermal store. An appropriate design of concrete mix can offer this thermal performance benefits, leading to a reduction in heating and cooling energy consumption in buildings [11, 12].

This situation raises a question about how best to design a concrete mix with respect to strength, thermal properties, environmental impact and $\mathrm{CO}_{2}$-e intensity of concrete. The objective of this paper is to identify the environmental impact and thermal performance of different concrete mix designs by considering both the embodied $\mathrm{CO}_{2}$-e and the impact on the thermal properties of concrete.

\section{1-1 Thermal performance of concrete}

Concrete is one of several building materials that possess high thermal properties. In cold seasons, high thermal mass building elements that contain concrete such as walls and floor slabs, absorb 
radiant heat from the sun during the day and release it gradually back into the system (space) during night when outside temperatures drop [13]. The distinct benefit of high thermal mass is to moderate changes in peak load of energy requirements due to fluctuations between inside and outside temperatures. High thermal mass causes a time lag between internal and external temperatures (Figure 1). It also stores heat which dampens the fluctuation between peaks. This often results in improved thermal comfort and less energy demand for heating and cooling[13]. Beside thermal mass, thermal properties of concrete mix design such as conductivity have a considerable influence on passive heating design strategy. An optimum design of concrete mix could either reduce escape of passive heating before being absorbed or re-released a stored heat before the colder night [14].

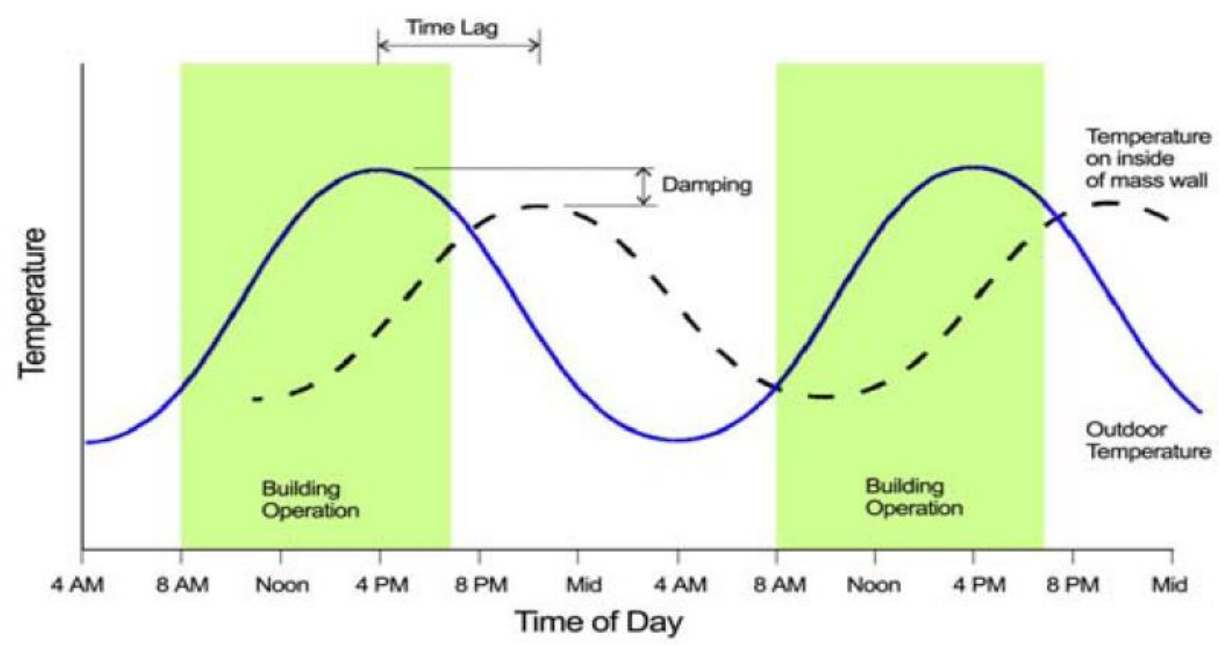

Figure 1 Damping and lag effect of thermal mass [13]

Thermal conductivity of concrete mix designs is influenced by the thermal properties of the ingredients such as cement, aggregates and the existing moisture [15]. Thermal conductivity of concrete is dependent on the type of aggregates used in the concrete mixture. Some published construction properties databases associate thermal conductivity to concrete density, for example ACI122R [15] and CIBSE [16]. Therefore, it is possible to take into the account some thermal properties of concrete mixes at the initial stage of the structural design of buildings. This study quantifies the thermal conductivity for different concrete mix designs. 


\section{1-2 Environmental aspects of Concrete}

The basic constituents of concrete are binder (cementitious materials), coarse and fine aggregates (or inactive mineral filler) and water. The properties of these materials, their combination, the effects of various admixtures and how it is handled during construction determine the properties of the in-situ concrete.

The major source of greenhouse emissions during the production of concrete is the Portland cement. The cement sector was responsible for 2,823 million metric tons (Mt) of embodied $\mathrm{CO}_{2}$-e in 2010 [17]. This related to almost $9 \%$ of global $\mathrm{CO}_{2}$-e emissions from burning of fossil fuels in 2010 [17]. Traditional methods to respond to this issue are the development of energy efficient cement production plants through improved technology, changes to energy sources used and the application of substitutes for clinker by using waste materials such as fly ash and ground granulated blast furnace slag [18-21].

The concrete industry is addressing some of the worries about environmental issues by supplementing or replacing the use of cement and other components that are associated with high embodied $\mathrm{CO}_{2}$-e. Several researchers have studied the possibility of cement replacement in the concrete with recycled materials [22-24]. The use of alternative cementitious materials remains the main path to the reduction of embodied $\mathrm{CO}_{2}$-e in the concrete industry [25]. Wimpenny [26] conducted a study in low $\mathrm{CO}_{2}$-e alternatives to concrete by exploring strategies being adopted and developed in 12 countries around the world. The results have been classified into seven groups as shown in Table 1 .

Table 1 embodied $\mathrm{CO}_{2}$-e for cementitious materials [26]

\begin{tabular}{|ccccc|}
\hline Group & Example & $\begin{array}{c}\text { Suggested } \\
\text { quantities }\end{array}$ & $\begin{array}{c}\text { embodied } \\
\mathrm{CO}_{2} \text {-e }\end{array}$ & References \\
\hline & Fly ash & $40 \%$ & Medium \\
Alternative & Slag & $80 \%$ & Low \\
cementitious & Silica fume & $10 \%$ & Low & {$[26,27]$} \\
materials & Metakaolin & $10 \%$ & Very high \\
& Municipal solid waste incinerator ash & ----- & Medium \\
& (MSWIA) & & Low & \\
Non-Portland cement & Geopolymer & ----- & Low & {$[28,29]$} \\
binders & Calcium sulphate based & & High & \\
& Calcium sulfoaluminate & ----- & Medium & {$[26]$} \\
\hline Low cement concrete & Magnesite based & ----- & Medium & {$[26]$} \\
\hline Ultra-high strength & Fibre reinforced superplasticiser silica fume & & & \\
\hline
\end{tabular}




\begin{tabular}{|c|c|c|c|c|}
\hline concrete & concrete (FRSSFC) & & & \\
\hline \multirow[b]{2}{*}{$\begin{array}{l}\text { Changes in Portland } \\
\text { cement manufacture }\end{array}$} & $\begin{array}{c}\text { Oxygen enrichment of kiln atmosphere to } \\
\text { enhance burning }\end{array}$ & ----- & Medium & \multirow[b]{2}{*}{ [28] } \\
\hline & $\begin{array}{c}\text { Belite cements } \\
\text { Alinite and Fluoralinite cement } \\
\text { Portland limestone cement } \\
\end{array}$ & ----- & $\begin{array}{c}\text { Very high } \\
\text {-------- } \\
\text {--------- } \\
\end{array}$ & \\
\hline $\begin{array}{c}\text { Alternative binder } \\
\text { types }\end{array}$ & Bituminous based materials (Agent C) & ----- & Very low & [26] \\
\hline Carbon capture & $\begin{array}{c}\text { Sequestering carbon from the kiln capturing } \\
\text { carbon in the concrete, e.g. Hemp (Lime } \\
\text { based binder and hemp) }\end{array}$ & ----- & Very low & [29] \\
\hline
\end{tabular}

The most commonly used alternative cementitious materials are Ground Granulated Blast Furnace Slag (GGBFS) and coal combustion fly ash. GGBFS is obtained as a by-product of iron and steel making and fly ash is obtained as a by-product of burning coal mainly for electricity generation. These cementitious materials are used to replace a portion of the cement in the concrete mix design. The production process of fly ash and GGBFS involve less greenhouse gas emissions compared with ordinary Portland cement [30].

Fly ash is a widely available material which, if not used in concrete, is an industrial waste with serious disposal problems. Worldwide, the majority of annual production of fly ash is disposed of as waste material in ash dams or in a landfill [31]. In Australia, about $20 \%$ of fly ash produced in coal-fired power stations is used in construction industry [32]. The Australian Standard, AS3582.1, sets specific requirements for fly ash and has classified it into three grades (fine, medium and coarse)[33]. If the physical properties of the fly ash do not comply with the AS3582.1 Standard requirements it cannot be used as a supplementary material in the cement and concrete industry [31]. The proportion of fly ash in blended cement typically changed from $15 \%$ to $30 \%$ and for some particular applications, this amount can be increased to $50 \%$ to $60 \%[34,35]$. The positive contribution of fly ash for reducing concrete embodied $\mathrm{CO}_{2}$-e has been quantified to be up to $44 \%$ when it substitutes $40 \%$ of Portland cement in a typical concrete mix design [36]. However, it should be noted that the decrease in the use of coal might also have a negative impact on supply of fly ash [37].

Other supplementary materials such as GGBFS can also be used to replace Portland cement in concrete. Substituting a portion of Portland cement with GGBFS can substantially reduce the negative environmental impact of concrete [38]. Fly ash and GGBFS can be added separately to the concrete 
mix. However, in comparison to the quantities of fly ash, the availability of GGBFS is limited. The worldwide production of GGBFS is only 25 million tonnes per year [39]. The proportion of GGFS in concrete typically varies from $40 \%$ to $60 \%$ of the overall amount of blended cement [40].

Other supplementary cementitious materials are silica fume, rice husk ash, and recycled ground glass. The availability of these materials are limited compared with the fly ash so their costs are relatively higher [41].

Geopolymer concrete is another alternative concrete in which an alkali activated aluminosilicate material is used as a replacement of traditional cement binders[42]. Geopolymers generally have a lower embodied $\mathrm{CO}_{2}$-e than cement but are currently significantly more expensive to produce [43].

Meanwhile, it has to be mentioned that there are some barriers to implementation of the new type of materials to achieve lightweight and/or geopolymer concrete. These barriers include regulatory, technical, supply chain and cost of geopolymer concrete [44-46]. There are currently several research programs that aim to remove the existing barriers for a wider application of geopolymer and/or lightweight concretes.

Aggregate characteristics have significant effects on physical properties of concrete (grade, moisture absorption, thermal conductivity, etc.). Aggregates have also potential to be reused as raw materials in the concrete at the end of life [47]. The choice of aggregates is very much related to a local supply chain. Quarries with adequate natural aggregates are being depleted in some regions and countries and the tendency to use of more crushed and manufactured aggregates is increasing [48]. From an emissions point of view, a distinction must be made between natural and crushed aggregate. Natural aggregates, such as sand and gravel, are the results of weathering and erosion and do not require any processing other than collection and transportation. Crushed aggregates, such as manufactured sand, are mined from quarries and require mechanical crushing. Flower and Sanjayan [49] showed that granite/hornfels as a crushed aggregate have GHG emissions of $45.9 \mathrm{~kg} \mathrm{CO}_{2}$-e/tonne and basalt as a natural aggregates have GHG emissions of $35.7 \mathrm{~kg} \mathrm{CO}_{2}$-e/tonne [49] . 
The water demand for concrete depends on the type of mix design and use of plasticising additives. The use of water in concrete leads to minimal embodied $\mathrm{CO}_{2}$-e, which leaves cement, coarse and fine aggregates, GGBFS and fly ash as the main material contributors to the environmental impact.

Previous studies into the environmental impact of the production of cementitious materials and aggregates have already yielded several estimates of the embodied $\mathrm{CO}_{2}$-e per tonne of concrete [25, $39,49,50]$. The embodied $\mathrm{CO}_{2}$-e are calculated by multiplying embodied $\mathrm{CO}_{2}$-e coefficients from proposed databases [1-4] for each grade of concrete by the quantity of concrete. This method suffers from a lack of comprehensive attention into the individual concrete components. The GHG emissions associated with each individual concrete component need to be sufficiently investigated [49]. Furthermore, the relationship between embodied $\mathrm{CO}_{2}$-e, thermal conductivity and alternative cementitious materials has not been sufficiently determined. The main objective of this study was to identify the relationship between low embodied $\mathrm{CO}_{2}$-e and low thermal conductivity for a large number of concrete mix designs. This paper analyses different concrete mix designs and compares the results when sourcing inputs from a number of available inventory databases.

\section{2-Methodology}

\section{2-1 Materials and Mix designs}

This study investigates 90 different concrete mix designs. The two primary performance variables are the grade and density of the concrete. The concrete mix designs were collected from 8 published journal papers and databases [51-59]. These mix designs represent some conventional (normal weight) and some advanced methods of concrete admixture $[52,54,56,57]$ that gives lightweight and ultra-lightweight concrete. Table 2 summarizes the concrete grades and the 90 mix cases of the different batches of concrete that were analysed in this paper. The reason to include novel forms of concrete admixture (such as Mix 27-41) in the paper was to point out their thermal properties and environmental impacts which have not been covered in the mainstream of studies. The concrete grades range from $28 \mathrm{MPa}$ to $87 \mathrm{MPa}$. The detailed concrete mix designs and ingredients are shown in Appendix 1. 
Table 2 Summary of concrete batches

\begin{tabular}{|c|c|c|c|c|c|c|}
\hline \multirow{2}{*}{$\begin{array}{l}\text { Mix } \\
\text { No. }\end{array}$} & \multirow{2}{*}{$\begin{array}{l}\text { Concrete } \\
\text { Grade } \\
\text { (MPa) }\end{array}$} & \multicolumn{4}{|c|}{ Composition of mix } & \multirow[b]{2}{*}{ Source } \\
\hline & & Binder & Aggregates & Admixture & Water & \\
\hline $\begin{array}{c}\text { Mix } \\
1-3\end{array}$ & 32,40 & $\begin{array}{l}\text { Portland cement, } \\
\text { GGBFS, fly ash }\end{array}$ & $\begin{array}{c}\text { natural aggregates, } \\
\text { recycled aggregates, } \\
\text { manufactured sand, fine } \\
\text { natural river sand }\end{array}$ & Water reducing & $\begin{array}{c}\text { Potable } \\
\text { water, } \\
\text { Reclaimed } \\
\text { water }\end{array}$ & CCAA [51] \\
\hline $\begin{array}{c}\text { Mix } \\
4-9\end{array}$ & $31.6-42.7$ & Portland cement & $\begin{array}{l}\text { natural aggregates, } \\
\text { manufactured sand, } \\
\text { Lightweight aggregate, } \\
\text { Furnace bottom ash }\end{array}$ & Water reducing & $\begin{array}{l}\text { Potable } \\
\text { water }\end{array}$ & $\begin{array}{l}\text { Zhang and Poon } \\
{[52]}\end{array}$ \\
\hline $\begin{array}{c}\text { Mix } \\
10-26\end{array}$ & $32,35,40$ & $\begin{array}{l}\text { Portland cement, } \\
\text { fly ash }\end{array}$ & $\begin{array}{c}\text { natural aggregates and } \\
\text { manufactured sand }\end{array}$ & ------ & $\begin{array}{l}\text { Potable } \\
\text { water }\end{array}$ & Berndt [53] \\
\hline $\begin{array}{c}\text { Mix } \\
27-41\end{array}$ & $33-69.4$ & $\begin{array}{l}\text { Portland cement, } \\
\text { cenosphere, silica } \\
\text { fume }\end{array}$ & $\begin{array}{c}\text { natural aggregates and } \\
\text { manufactured sand }\end{array}$ & $\begin{array}{l}\text { Superplasticiser } \\
\text {, shrinkage } \\
\text { reduction, } \\
\text { Viscosity } \\
\text { modify agent, } \\
\text { Polyethylene } \\
\text { fibers, Silane }\end{array}$ & $\begin{array}{l}\text { Potable } \\
\text { water }\end{array}$ & $\begin{array}{l}\text { Wu, Wang, } \\
\text { Monteiro and } \\
\text { Zhang [54] }\end{array}$ \\
\hline $\begin{array}{c}\text { Mix } \\
42-57\end{array}$ & $38-55$ & $\begin{array}{l}\text { Portland cement, } \\
\text { GGBFS, fly ash, } \\
\text { silica fume }\end{array}$ & $\begin{array}{l}\text { natural aggregates, } \\
\text { recycled aggregates, }\end{array}$ & ------ & $\begin{array}{l}\text { Potable } \\
\text { water }\end{array}$ & $\begin{array}{c}\text { Damdelen, } \\
\text { Georgopoulos and } \\
\text { Limbachiya [55] }\end{array}$ \\
\hline $\begin{array}{c}\operatorname{Mix} \\
58-69\end{array}$ & $23-43.9$ & $\begin{array}{l}\text { Portland cement, } \\
\text { fly ash }\end{array}$ & $\begin{array}{c}\text { natural aggregates, } \\
\text { Lightweight aggregate*, } \\
\text { Glass bubble }\end{array}$ & ------ & $\begin{array}{l}\text { Potable } \\
\text { water }\end{array}$ & $\begin{array}{l}\text { Yun, Jeong, Han } \\
\text { and Youm [56] }\end{array}$ \\
\hline $\begin{array}{c}\text { Mix } \\
70-75\end{array}$ & $33.6-48.6$ & Portland cement, & natural aggregates & ------ & $\begin{array}{l}\text { Potable } \\
\text { water }\end{array}$ & $\begin{array}{l}\text { Marinkovic, } \\
\text { Radonjanin, } \\
\text { Malesev and } \\
\text { Ignjatovic [57] }\end{array}$ \\
\hline $\begin{array}{c}\operatorname{Mix} \\
76-79\end{array}$ & $41.5-44.2$ & Portland cement, & $\begin{array}{l}\text { natural aggregates, } \\
\text { recycled aggregates, }\end{array}$ & ------ & $\begin{array}{l}\text { Potable } \\
\text { water }\end{array}$ & $\begin{array}{c}\text { Tošić, Marinković, } \\
\text { Dašić and Stanić } \\
{[58]}\end{array}$ \\
\hline $\begin{array}{c}\text { Mix } \\
80-90\end{array}$ & 32 & $\begin{array}{l}\text { Portland cement, } \\
\text { GGBFS, fly ash, }\end{array}$ & natural aggregates & ------ & $\begin{array}{l}\text { Potable } \\
\text { water }\end{array}$ & $\begin{array}{l}\text { O'Moore and } \\
\text { O'Brien [59] }\end{array}$ \\
\hline
\end{tabular}

*Lightweight aggregate consists of manufactured aggregate (shale, slate and clay) and Glass bubble.

This study considers each individual concrete component in order to estimate the equivalent greenhouse emissions and thermal conductivity of the mixed design. The embodied $\mathrm{CO}_{2}$-e for a variety of concrete mix designs was quantified by collecting relative embodied $\mathrm{CO}_{2}$-e coefficients for each individual concrete component from existing studies [49, 60-62]. 
The estimated emission coefficient for each material was multiplied by the respective quantity of the material, and the resulting embodied $\mathrm{CO}_{2}$-e was summed up for each mix design. The comparison includes the results obtained from this study against six different embodied $\mathrm{CO}_{2}$-e data inventories, namely; ICE [1], Crawford [2], Alcorn [3], eTool [4] and BPIC (an average industrial practice database) [5] and AusLCI [6]. As the study undertaken by Crawford covers embodied energy rather than embodied $\mathrm{CO}_{2}$-e, a conservative coefficient of $10 \%$ (based on the ratio used in eTool database) was used to convert data into embodied $\mathrm{CO}_{2}$-e $\left(\mathrm{kg} \mathrm{CO}_{2}\right.$-e $)$. Linear interpolation was used for Crawford databases to estimate the coefficient for the embodied $\mathrm{CO}_{2}$-e of all grades of concrete that are proposed in the concrete mix data of this study. For the ICE database, linear interpolation was used to estimate the embodied $\mathrm{CO}_{2}$-e coefficient when different percentages of cement were replaced with slag and/or fly ash. Calculation of the thermal conductivity of each mix design follows the ACI122R [15] guideline. ACI122R proposes that the thermal conductivity of a concrete mixture is based on the individual material properties comprising the mixture (aggregate) and the oven dry density of the mixture $\left(\mathrm{kg} / \mathrm{m}^{3}\right)$.

\section{2-2 Embodied Carbon Dioxide Equivalent Emissions}

The emission factors for binders, aggregates and admixtures were obtained from Flower and Sanjayan [49] and were based on the Australian Green house office factors and method workbook [63]. The emission factor for recycled aggregates was collected from ARRB Group report [61]. The embodied emission associated with manufactured aggregates was considered the same as the natural aggregates in regards to the upstream stage of the production process [64]. The emission associated with potable water and captured water was based on the results of Rouwette [60]. The boundary of the system for calculating the total embodied $\mathrm{CO}_{2}$-e is depicted in Figure 2. This study considered the embodied $\mathrm{CO}_{2}$-e associated with concrete and concrete materials from cradle to gate. This system includes all the steps from extraction of raw materials, transport to the concrete plant, mixing and production of concrete by considering relevant consumed energy (Diesel fuel, LPG fuel and electricity). The process of transportation and placement of concrete is excluded in this study. Table 3 summarizes the final embodied $\mathrm{CO}_{2}$-e coefficients that are related to individual concrete components. 


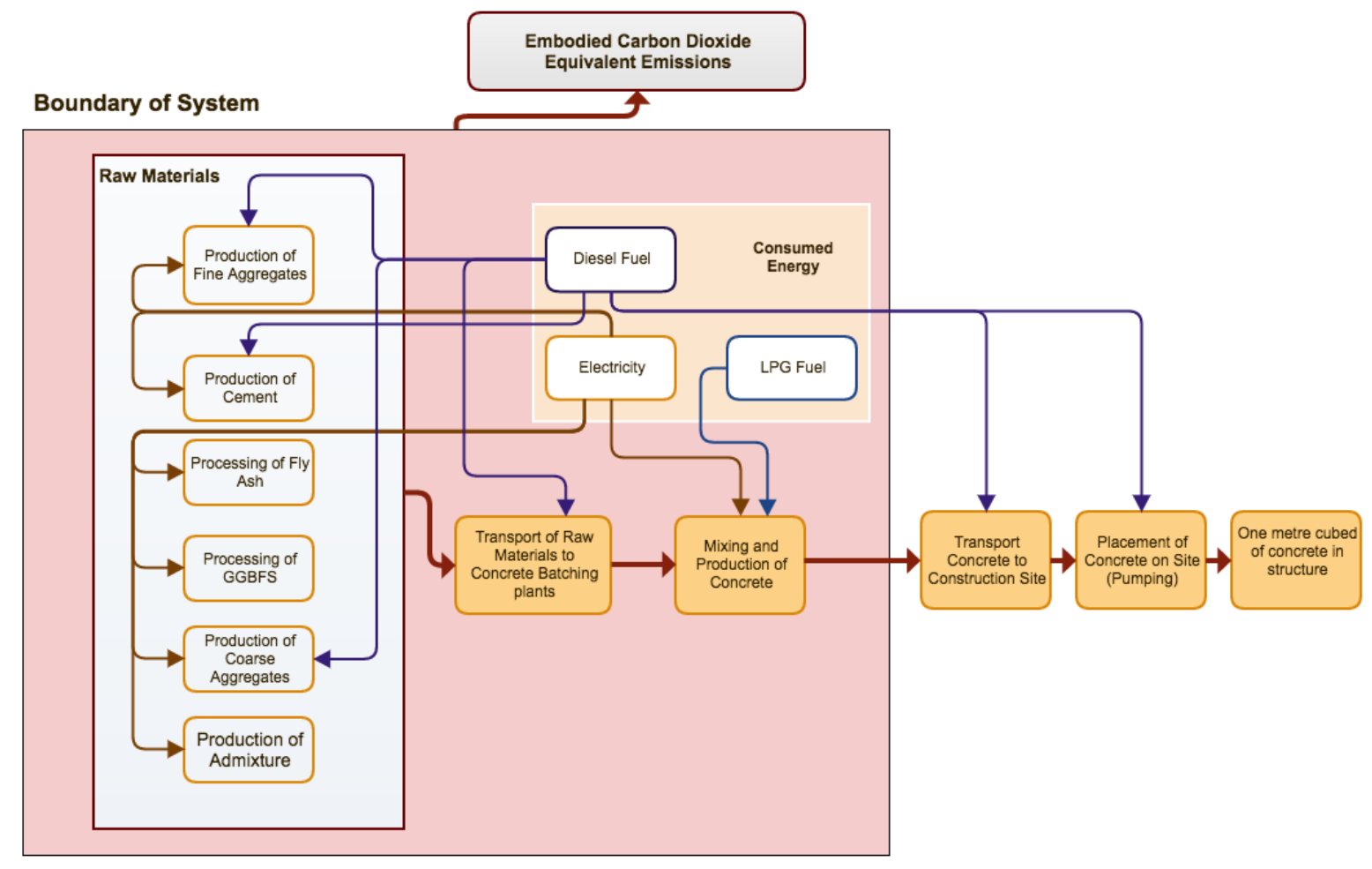

Figure 2 Concrete embodied CO2-e system diagram

Table 3 Final embodied CO2-e coefficients

\begin{tabular}{|c|c|c|c|}
\hline Activity & Material & Emissions coefficient & References \\
\hline \multirow{5}{*}{$\begin{array}{c}\text { Binder } \\
\text { (t CO2-e/ tonne) }\end{array}$} & Type of Portland cement & 0.820 & \multirow{5}{*}[49,62]{} \\
\hline & $\begin{array}{l}\text { Ground Slag ; Ground Granulated blast } \\
\text { furnace }\end{array}$ & 0.143 & \\
\hline & Fly ash or pulverized fuel ash & 0.027 & \\
\hline & Furnace bottom ash & 0.027 & \\
\hline & cenosphere & 0.027 & \\
\hline \multirow{4}{*}{$\begin{array}{c}\text { Aggregates } \\
\text { (t } \mathrm{CO}_{2} \text {-e/ tonne) }\end{array}$} & Natural aggregates & 0.0459 & \multirow{4}{*}[49,61]{} \\
\hline & Recycled aggregates & 0.004 & \\
\hline & Manufactured Sand & 0.0139 & \\
\hline & Fine natural river sand & 0.0139 & \\
\hline \multirow{2}{*}{$\begin{array}{c}\text { Admixture } \\
\left(\mathrm{t} \mathbf{C O}_{2} \text {-e/ L) }\right.\end{array}$} & Water reducing admixture & $2.2 \times 10^{-6}$ & \multirow{2}{*}{ [49] } \\
\hline & Superplasticiser & $5.2 \times 10^{-6}$ & \\
\hline \multirow{2}{*}{$\begin{array}{c}\text { Water } \\
\text { (t } \mathbf{C O}_{2} \text {-e/ tonne) }\end{array}$} & Potable water & $7 \times 10^{-4}$ & \multirow{2}{*}[60]{} \\
\hline & Captured/ Reclaimed water & $7 \times 10^{-5}$ & \\
\hline
\end{tabular}




\section{3-Results and discussion}

\section{3-1 Embodied emissions}

The resulting cradle to gate life cycle embodied $\mathrm{CO}_{2}$-e of the 90 concrete mixtures are shown in Figure 3. The quantities of embodied $\mathrm{CO}_{2}$-e relate to $1 \mathrm{~m}^{3}$ of concrete. As the results in Figure 3 show, the amount of embodied $\mathrm{CO}_{2}$-e was influenced by variations in the concrete mixture.

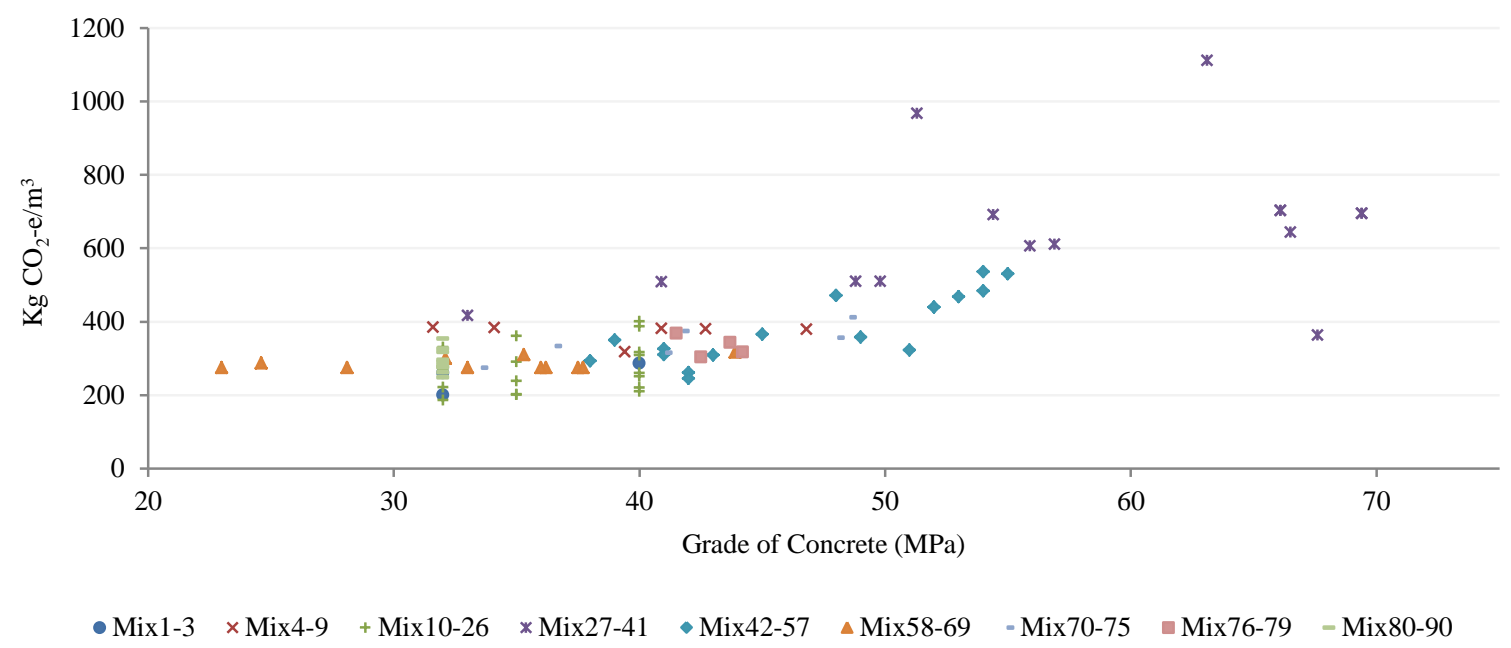

Figure 3 Embodied $\mathrm{CO}_{2}$-e for different grades of Concrete

Figure 4 illustrates the variation of embodied $\mathrm{CO}_{2}$-e per $\mathrm{m}^{3}$ of concrete for two selected groups of concrete (32-35 MPa and 38-42 MPa). The data was categorised into the common standardised grades of 32 and $40 \mathrm{MPa}$ due to variability in the expected concrete strength [65] and also because these two categories are popular in the structural design of buildings. The graphically depicted embodied $\mathrm{CO}_{2}-\mathrm{e}$ results show the variation along with different mix designs for the two selected groups. The statistical distribution of data displays interquartile ranges between 72.9 and $103.1 \mathrm{Kg} \mathrm{CO}_{2}-\mathrm{e} / \mathrm{m}^{3}$ for group 3235MPa and 38-42 MPa respectively (Figure 4).

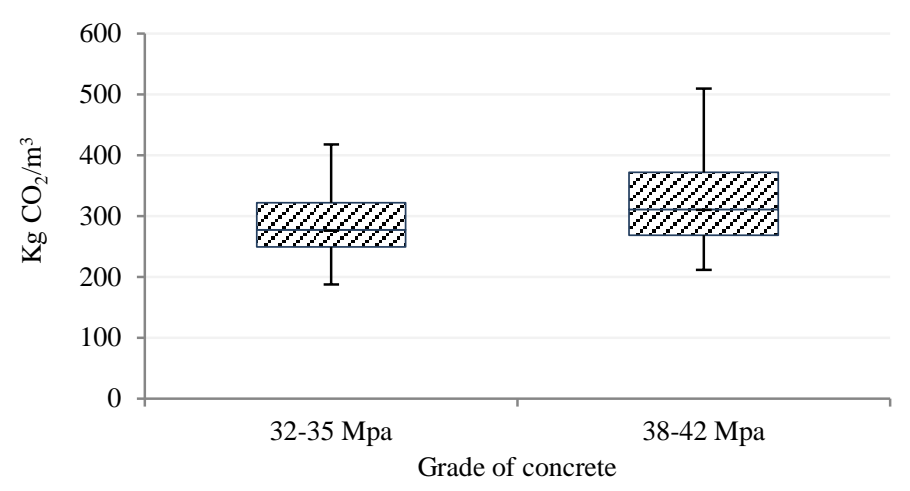


For a grade of $32-35 \mathrm{MPa}$ concrete the embodied $\mathrm{CO}_{2}$-e range from 187.2 to $417.5 \mathrm{~kg} \mathrm{CO}_{2}-\mathrm{e} / \mathrm{m}^{3}$ by a central tendency of $277 \mathrm{~kg} \mathrm{CO}_{2}-\mathrm{e} / \mathrm{m}^{3}$. The detailed results in Figure 5 shows mix number 13 and mix number 32 achieved the lowest and highest embodied $\mathrm{CO}_{2}$-e respectively when compared with the other mixes. For mix design number 13, 65\% of binder was blast furnace slag and $35 \%$ was general Portland cement. The resulted mix with the lowest emissions (mix design number 32) includes 58\% general Portland cement, 37\% cenosphere and 5\% silica fume.

For group 38-42 $\mathrm{MPa}$, the embodied $\mathrm{CO}_{2}$-e was calculated to vary from 211 to $509 \mathrm{~kg} \mathrm{CO}_{2}$-e/m $\mathrm{m}^{3}$ by median value of $311 \mathrm{~kg} \mathrm{CO}_{2}-\mathrm{e} / \mathrm{m}^{3}$ as shown in Figure 6. Mix number 22 and 36 produced the lowest and highest amount of embodied $\mathrm{CO}_{2}$-e per $\mathrm{m}^{3}$ of concrete, respectively. Mix 22 binder contains $35 \%$ Portland cement and 65\% blast furnace slag. Mix 36 consisted of 55\% Portland cement, 40\% cenosphere and $5 \%$ silica fume.

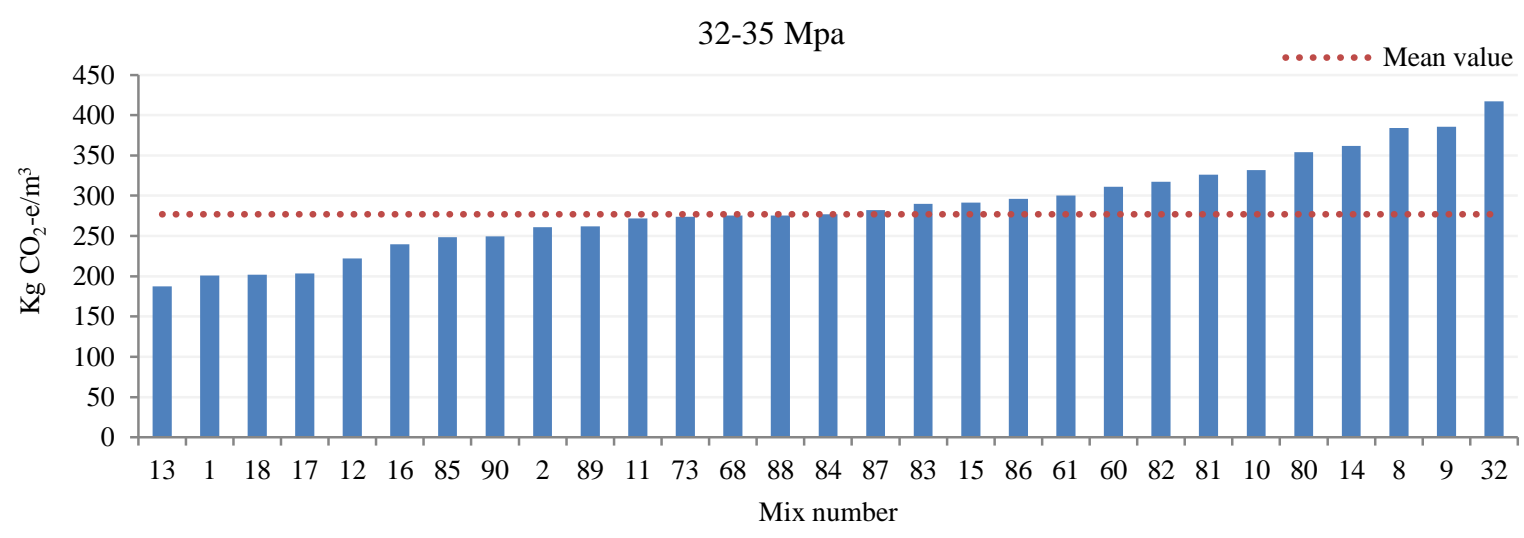

Figure 5 Embodied CO2-e for 32-35 MPa

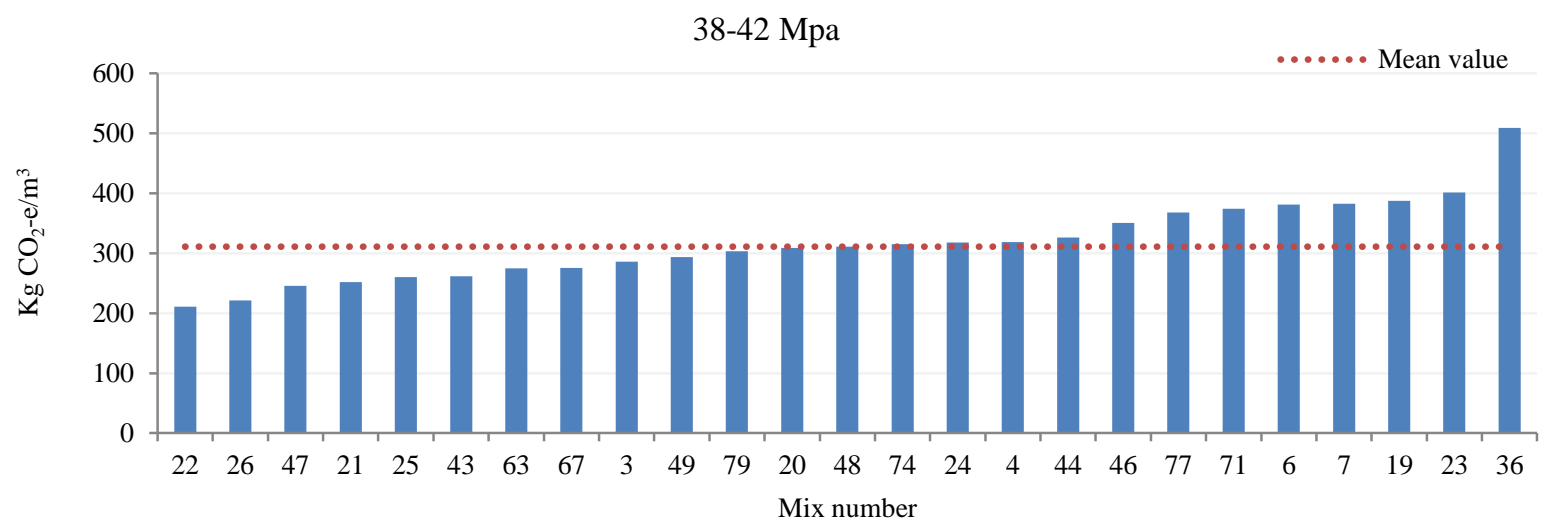

Figure 6 Embodied CO2-e for 38-42 MPa concrete 
Various methods have been proposed for reducing the embodied $\mathrm{CO}_{2}$-e of Portland cement [43, 6668]. For instance, the efficiency of making cement can be improved by reducing the proportion of clinker and replacing it by ground granulated blast furnace slag (GGBFS). Also, supplementary cementitious and pozzolanic materials, such as GGBFS, fly ash, silica fume, rice husk ash and metakaolin have been considered as a replacement of Portland cement $[43,69,70]$. This study quantifies the effect from replacing portions of Portland cement with fly ash and GGBFS. The results show that concrete mixes with fly ash have $8 \%$ to $30 \%$ less embodied $\mathrm{CO}_{2}$-e compared to the mix with $100 \%$ Portland cement (mix 80-85). GGBFS was found to be capable of reducing concrete embodied $\mathrm{CO}_{2}$-e by $15.5 \%$ in the concrete mixture (mix 86-90). It should also be mentioned that the emissions associated with the production of concrete are related to parameters such as the availability of raw materials in the region and as the amount of emissions produced during transportation. This study considered the embodied $\mathrm{CO}_{2}$-e associated with concrete and concrete materials from cradle to gate and such parameters (transportation, region, etc.) were not taken into account.

\section{3-2 Variations in embodied $\mathrm{CO}_{2}$-e coefficient}

The estimated embodied $\mathrm{CO}_{2}$-e emissions for the two selected concrete grade groups were compared between the Crawford, ICE, Alcorn, eTool, BPIC and AusLCI inventory embodied $\mathrm{CO}_{2}$-e databases. Figure 7 and Figure 8 illustrate the embodied $\mathrm{CO}_{2}$-e across mixture designs for grade 32-35 $\mathrm{MPa}$ and 38-42 MPa. 


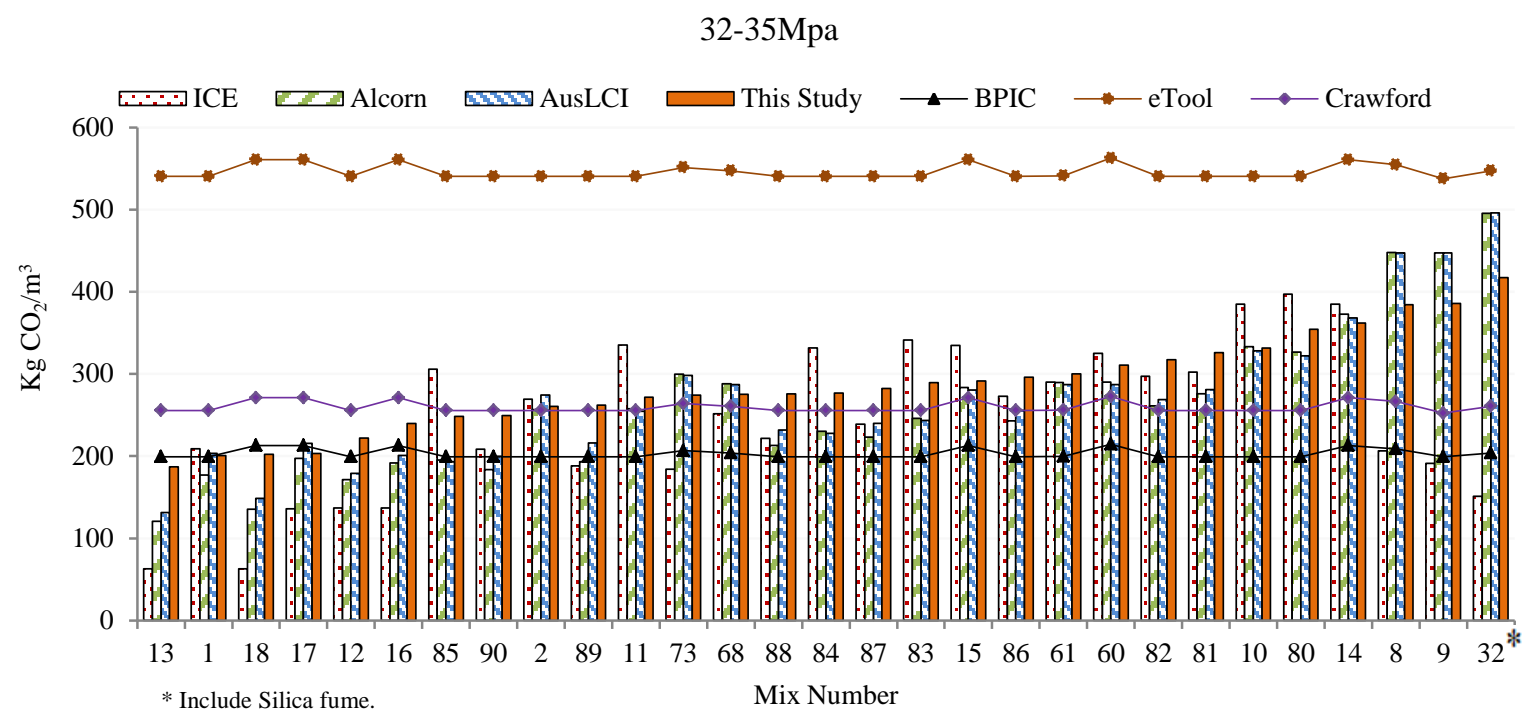

Figure 7 Embodied $\mathrm{CO}_{2}$-e across inventory databases for 32 MPa concrete

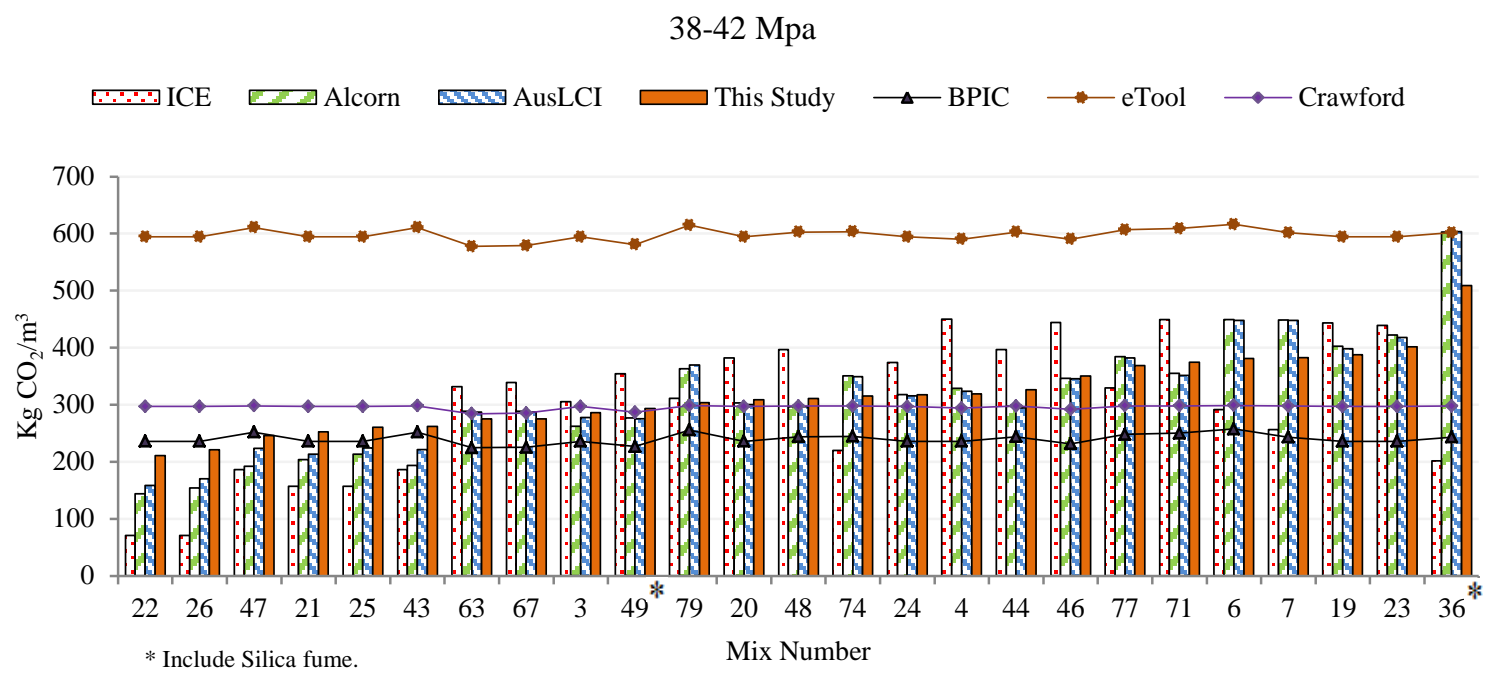

Figure 8 Embodied $\mathrm{CO}_{2}$-e across inventory databases for $40 \mathrm{MPa}$ concrete

The comparison shows that the amount of embodied $\mathrm{CO}_{2}$-e for grade $32 \mathrm{MPa}$ can vary significantly from 62.8 to $495.9 \mathrm{~kg} \mathrm{CO}$-e/ $\mathrm{m}^{3}$ of concrete depending on the type of mix design and inventory database. Similarly, significantly different embodied $\mathrm{CO}_{2}$-e for grade $40 \mathrm{MPa}$ concrete were obtained (from 70.3 to $616.3 \mathrm{~kg} \mathrm{CO}_{2}-\mathrm{e} / \mathrm{m}^{3}$ of concrete) across the different mix designs and databases. The resulting embodied $\mathrm{CO}_{2}$-e based on Crawford, eTool and BPIC databases have treated concrete as one specific product and have proposed an individual coefficient for each grade of concrete regardless of the mix of ingredients. The minor changes (less than 4\%) in the results of each database including BPIC, eTool and Crawford is due to the changes in density of concrete mix designs and the embodied $\mathrm{CO}_{2}$-e coefficients that are a function of concrete density. On the other hand, the concrete mix 
comparison results from the ICE database and this study (using the coefficients of Table 3) show that mix designs 13 for $32 \mathrm{MPa}$ concrete and 22 for $40 \mathrm{MPa}$ concrete have the lowest embodied $\mathrm{CO}_{2}$-e. This stems from replacing $65 \%$ of cement with blast furnace slag. As expected, the maximum embodied $\mathrm{CO}_{2}$-e was recorded for mix 32 and mix 36 for group 32 and $40 \mathrm{MPa}$, respectively in which no supplementary cementitious materials were used (i.e. 100\% Portland cement was used).

From the data in Figure 7 and 8, it is apparent that the results based on AusLCI and Alcorn analysis represent less than $4 \%$ difference and both databases are capable to illustrate variations between mix designs. Similar to the results of this study, the highest embodied energy was recorded for the mix designs 36 and 32 for a grade of 32 and $40 \mathrm{MPa}$, respectively. The lowest embodied emission was archived through the mix designs 13 and 22.

The current databases are unable to adequately address the effect of silica fume and cenosphere as alternative cementitious materials used in the concrete mix designs 32, 36 and 49 (as shown in Figure 7 and 8). However, it is reasonable to assume that there is no environmental impact associated to silica fume as it is a by-product of the production of metallurgical grade silicon [71]. In addition, the embodied $\mathrm{CO}_{2}$-e associated with cenosphere is similar to $\mathrm{CO}_{2}$-e of fly ash and was therefore assumed to be the same as fly ash in the paper, as both materials are by-products from the production of power within coal fired power stations [62].

The resulting embodied $\mathrm{CO}_{2}$-e when using different inventory databases are summarised in Figures 9 and 10. The embodied $\mathrm{CO}_{2}$-e values across Alcorn, Crawford and eTool databases vary from 255 to $540 \mathrm{~kg} \mathrm{CO}_{2}-\mathrm{e} / \mathrm{m}^{3}$ for group 32-35 MPa and from 290 to $590 \mathrm{~kg} \mathrm{CO}_{2}-\mathrm{e} / \mathrm{m}^{3}$ for group 38-42 $\mathrm{MPa}$. The differences could be explained by the variations in the method of analysis used in each database, the different system boundaries, source of data and quality of input in the calculation of the upstream process [72].

The embodied $\mathrm{CO}_{2}$-e factor from ICE database varies for each different mix design with exception of mix design 32, 36, 39 which includes silica fume and cenosphere. This database considers different proportions of cement and cementitious material such a slag and fly ash in the concrete. In terms of the maximum proportion of the slag in mix designs 13 and 25, the ICE embodied $\mathrm{CO}_{2}$-e coefficients 
are 62.8 and $70.3 \mathrm{~kg} \mathrm{CO}_{2}-\mathrm{e} / \mathrm{m}^{3}$. For specific mix designs, the ICE results match closely with those obtained from Crawford (mix 1, 3, 68, 79) and Alcorn (mix 43, 47,61). For mix designs 6 and 9 the ICE results are the same as the results from BPIC.

A comparison analysis between AusLCI, Alcorn and the current study demonstrates considerable variation in embodied $\mathrm{CO}_{2}$-e of the concrete mix designs. The average differences are $16 \%$ and $7 \%$ for grade 32 and $40 \mathrm{MPa}$, respectively. These differences in results are due to variations in the embodied $\mathrm{CO}_{2}$-e coefficients for cement (general purpose), GGBFS, fly ash and type of aggregates (natural and manufactured) in concrete mix designs. For instance, AusLCI proposes the factor of 0.994 (tonne $\mathrm{CO}_{2}$-e) for producing the average of 1 tonne GP cement in Australian, while this number 18\% higher than the coefficients proposed in Crossin [71] and Flower [49] studies (used in this study). Similarly, AusLCI proposes a higher emission factor for manufacturing GGBFS and recycled aggregates and lower embodied $\mathrm{CO}_{2}$-e for producing fly ash than this study (based on [49]). The embodied $\mathrm{CO}_{2}$-e associated with the production of natural aggregates is not directly reported in a transparent way in AusLCI, while ARRB gives a value of $3.97 \mathrm{~kg} \mathrm{CO} 2-\mathrm{e}$ per tonne of materials [61]. Also, Alcorn's database does not adequately address the embodied $\mathrm{CO}_{2}$-e associated with alternative cementitious materials such as fly ash and GGBFS.

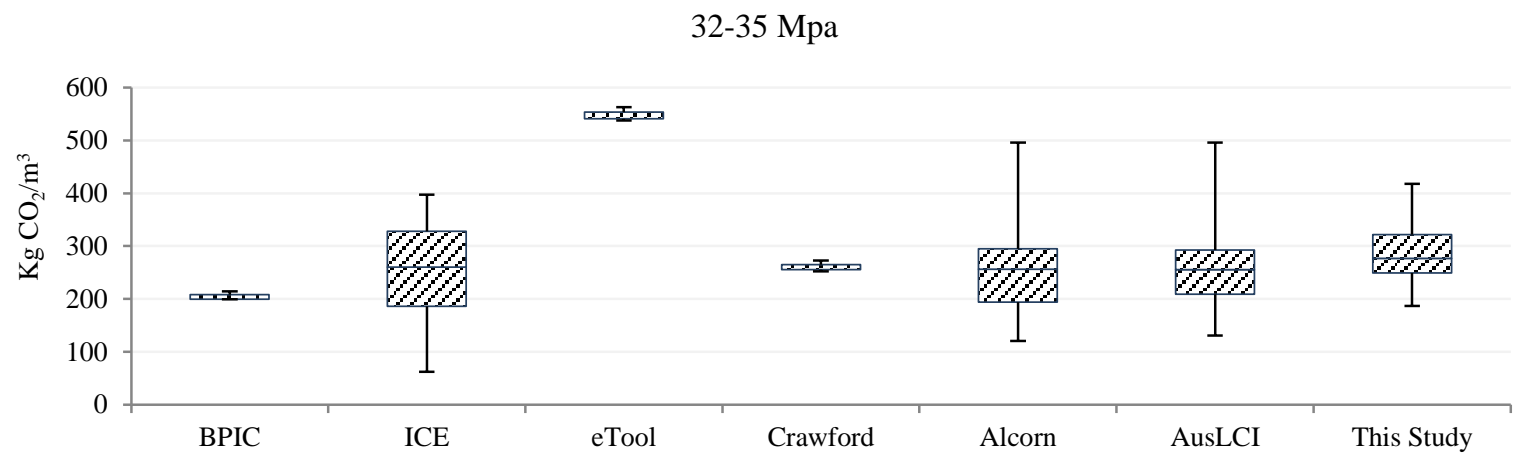

Figure 9 Variation in embodied $\mathrm{CO}_{2}$-e for different databases (32-35 MPa) 


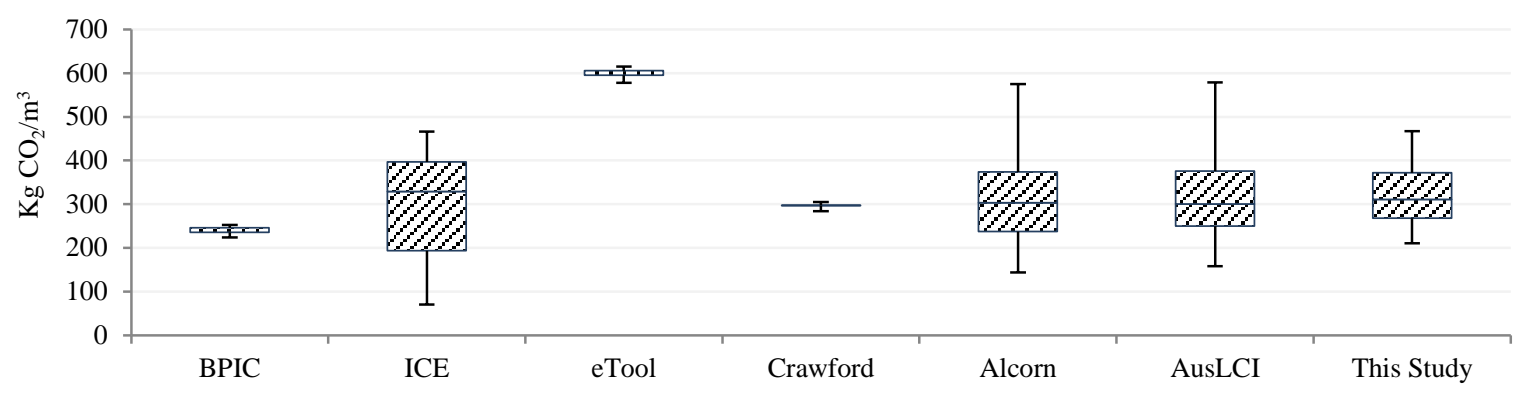

Figure 10 Variation in embodied $\mathrm{CO}_{2}$-e for different databases (38-42 $\left.\mathrm{MPa}\right)$

In summary, it can be seen these variations in the embodied $\mathrm{CO}_{2}$-e of different concrete mix designs could affect the overall lifecycle assessment of a building and building materials. As it can be seen from the results, one product might get attributed lower embodied $\mathrm{CO}_{2}$-e than another product in one database while the same product in another database could get attributed the same or higher emissions. For example, the results based on AusLCI, Alcorn, ICE and those produced from the additional cases of our study show that mix designs 13, 18, 22, 26 represent the lowest amount of embodied $\mathrm{CO}_{2}$-e among the 90 mix designs. These four mix designs (13, 18, 22 and 26) have used an alternative cementitious material by replacing $65 \%$ of cement binder with GGBFS. However, the results from eTool, BPIC and Crawford databases do not show these differences of embodied $\mathrm{CO}_{2}$-e across the different concrete mixes. In addition, consideration needs to be given to the variation associated with production, manufacturing techniques, type of fuel used and the source of raw materials and transportation distance across different geographic location. This variation can even be quite significant between areas within the same country $[2,73]$. The differences found between the databases point out the need for transparency with regard to their ability to analyse individual concrete components. Meanwhile, the summary of the results (Figures 9 and 10) quantify the variations which could promote better comparisons for research which employs these databases.

\section{3-3 Thermal conductivity of concrete mix design}

A comparative assessment was performed to estimate the thermal conductivity of each concrete mix designs. The thermal conductivities were obtained for all 90 mixes from ACI122R [15]. In addition, data for mixes 27 to 57 were reported in the relevant published articles [54, 55]obtained. The 
proposed ACI values were taken from Table 3.a of ACI122R-2014 and are based on practical thermal conductivity design values for normal weight (2240 to $2400 \mathrm{~kg} / \mathrm{m}^{3}$ ), light and ultra-lightweight concrete (less than $1840 \mathrm{~kg} / \mathrm{m}^{3}$ ). Figure 11 illustrates both theoretical and experimental thermal conductivity values for all 90 concrete mix designs. This paper used the data obtained from ACI122R method to ensure consistency comparisons across all mix designs. As expected, it can be seen that the thermal conductivity is influenced by the variation in the concrete mixture.

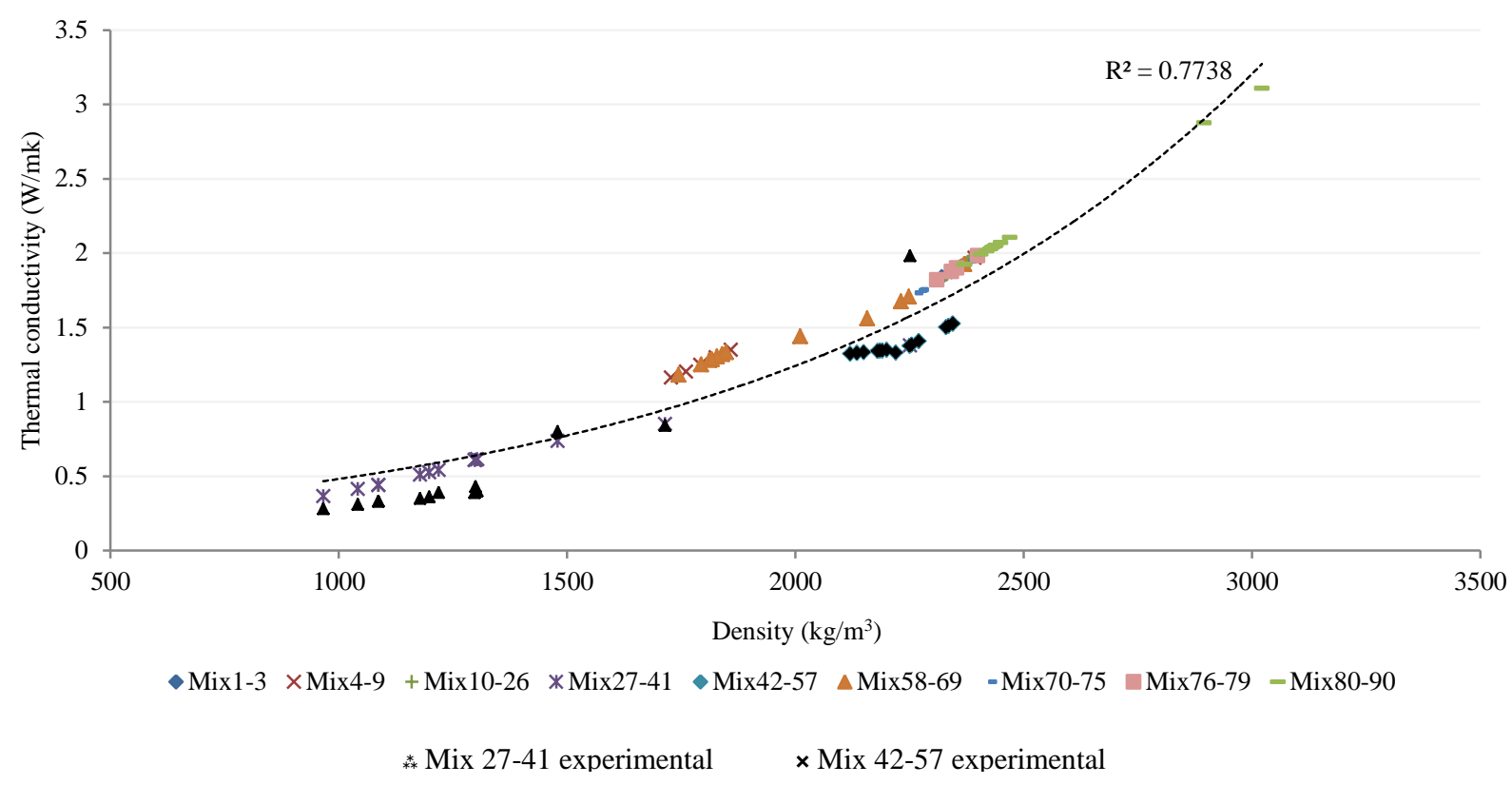

Figure 11 Thermal conductivity of concrete mix designs

The study shows that the type of cement and aggregate affected the density and thermal conductivity of the concrete. The replacement of normal aggregate with the lightweight aggregate reduces the density and thermal conductivity of the concrete. The data illustrate that by using lightweight aggregate to replace natural coarse aggregate, the concrete density can be changed from 2320 to 1727 $\mathrm{kg} / \mathrm{m}^{3}$. The thermal conductivity of concrete was decreased when lightweight aggregates introduced into the mix designs. For example, when comparing the results between mix 4 and mix 9 it can be seen that with the decreases of the proportion of aggregates in a mix design the thermal conductivity of the concrete decreased from 1.96 to $1.16(\mathrm{~W} / \mathrm{mK})$.

Figure 12 represents the variation in thermal conductivity per $\mathrm{m}^{3}$ of concrete across the two selected grades, i.e. mix design groups $32-35 \mathrm{MPa}$ and $38-42 \mathrm{MPa}$. This variation in results is due to changes 
in the proportion of normal and lightweight aggregates in the concrete mixture. For example, mix designs 32 and 36 have the lowest thermal conductivity while having a lower density than all other mix designs in groups 32-35 MPa and 38-42 MPa, respectively.

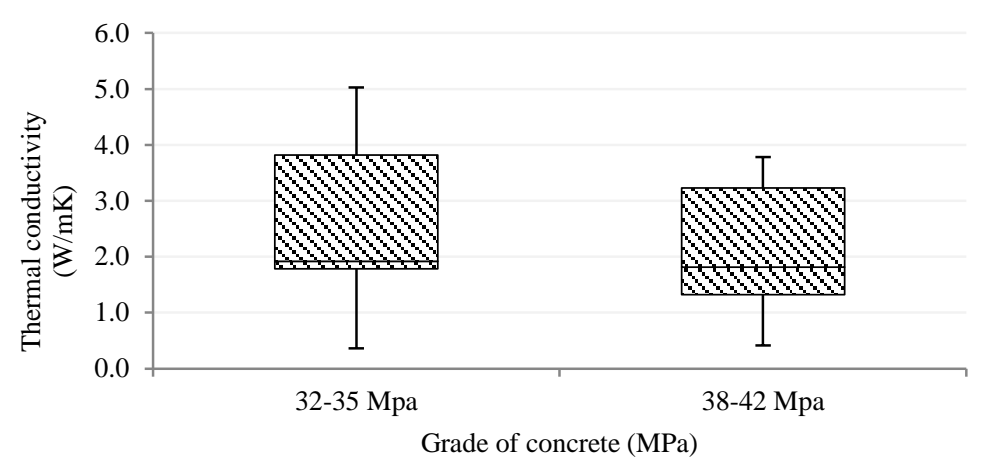

Figure 12 Variation in thermal conductivity between concrete mix designs

With a brief review of previously published values, it can be seen that the estimated thermal conductivity for grade $32-35 \mathrm{MPa}$ and $38-42 \mathrm{MPa}$ concrete mixes could vary from as high as 3.1 $\mathrm{W} /(\mathrm{m} . \mathrm{K})$ to as low as $0.36 \mathrm{~W} /(\mathrm{m} . \mathrm{K})$. For a grade of $32-35 \mathrm{MPa}$, the lowest and highest thermal conductivity is found for a mix design 32 and 82, respectively. For 38-42 MPa, the lowest thermal conductivity $(0.31 \mathrm{~W} /(\mathrm{m} . \mathrm{K}))$ can be achieved by through mix design 36 .

The comparison of all embodied $\mathrm{CO}_{2}$-e obtained from Table 3 and thermal conductivity of mix designs show different correlations between two variables. Figure 13 plots changes of the embodied $\mathrm{CO}_{2}$-e results against thermal conductivity of concrete mix designs and also shown in Appendix 1.

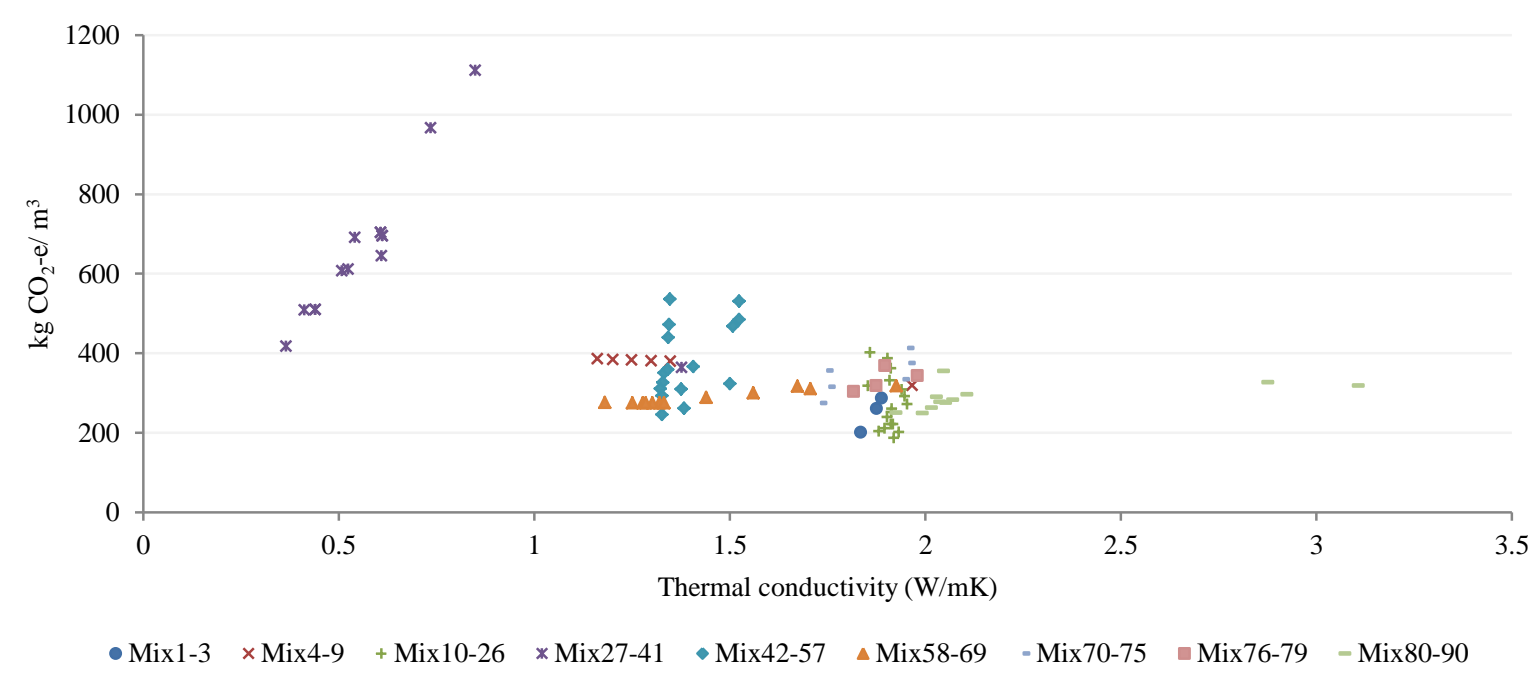

Figure 13 Embodied CO2-e versus thermal conductivity across all concrete mix designs 
For mix designs 27-41, the results represent a positive gradient between changes of thermal conductivity and embodied $\mathrm{CO}_{2}$-e. In the other words, the amount of embodied $\mathrm{CO}_{2}$-e was increased by increasing the thermal conductivity of concrete. It was noted that the rate of changes embodied $\mathrm{CO}_{2}$-e and thermal conductivity for mixes $27-41$ are much higher than the other mixes. These changes are due to the presence of high proportion of Portland cement and low-density aggregates in the mixes 27-41. On the other hand, the results from several other mix designs demonstrate considerable scatter in thermal conductivity without changing embodied $\mathrm{CO}_{2}$-e values and vice versa. This can be seen, for example, in mix designs 4 to 9 , where the changes in thermal conductivities ranged up to $41 \%$ while there was just $17 \%$ change in embodied $\mathrm{CO}_{2}$-e value.
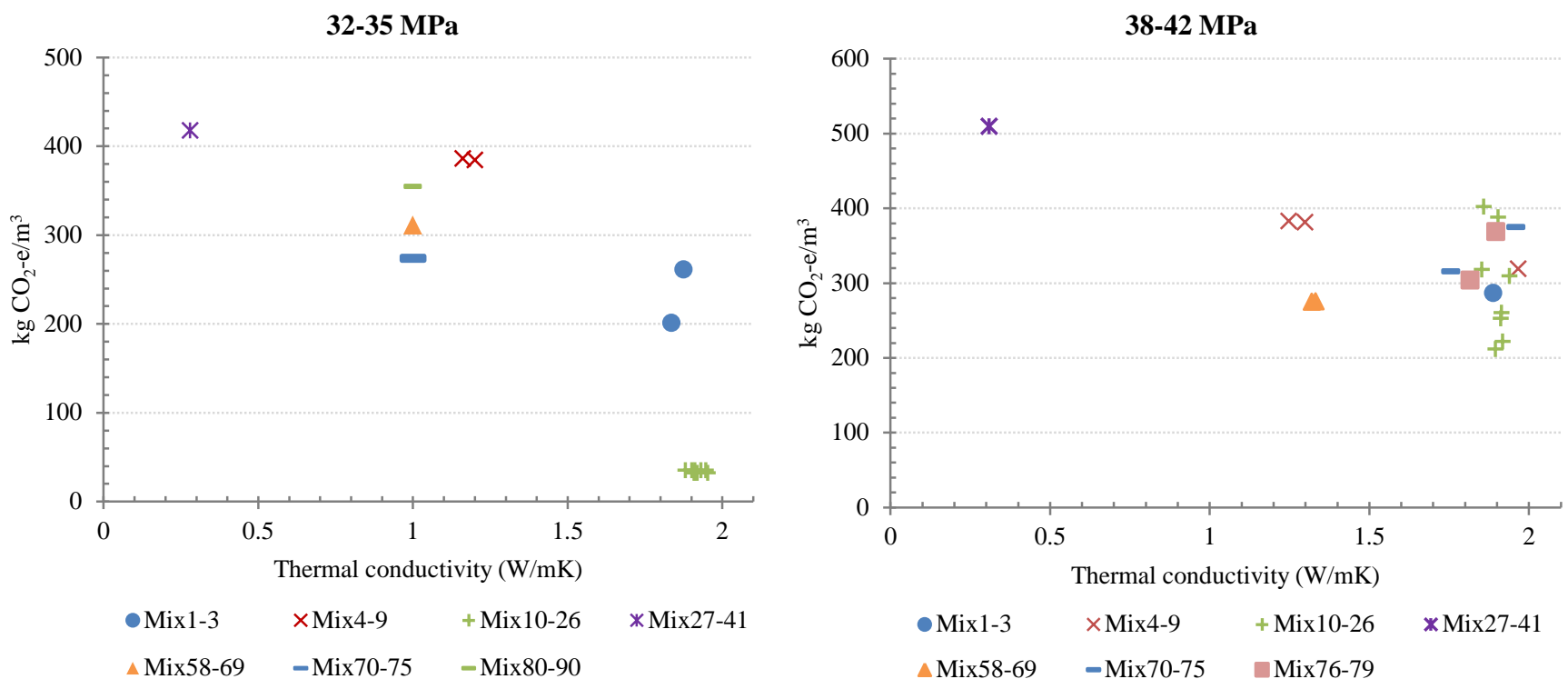

Figure 14 Embodied CO2-e against the thermal conductivity for Grade 32-35 MPa and 38-42 MPa

Figure 14 illustrates a comparison between the thermal conductivity and the embodied $\mathrm{CO}_{2}$-e of the $32-35 \mathrm{MPa}$ and $38-42 \mathrm{MPa}$ concrete groups. It can be seen mixes $27-41$ provide lowest thermal conductivity while having the highest embodied $\mathrm{CO}_{2}$-e. Mix designs 10-26 are associated with the lowest amount of embodied $\mathrm{CO}_{2}-\mathrm{e}$ while presenting the highest thermal conductivity in both groups. In group 38-42 MPa, the thermal conductivity values associated with mix design 10-26 do not vary significantly while the values of the embodied $\mathrm{CO} 2$-e can range from approximately 200 to $400 \mathrm{~kg} \mathrm{CO}_{2}$-e/m³ .

As previously discussed, the variations of the results are shown in Figures 11-14 are associated with the changes in quantity and type of aggregate and binder materials in the concrete mix design. Also, 
The lower thermal conductivity suppresses the energy charging/discharging rates [74]. This may have a positive potential effect on the overall energy performance of buildings in compare to the traditional concrete. Concrete with the low thermal conductivity results in higher thermal resistance than conventional concrete, which can slow down heat gain and energy losses for periods of time $[75,76]$. However, the optimal range for thermal conductivity of a concrete mix has to be considered to reduce either escape of passive heating before being absorbed or re-released a stored heat before the colder night [14]. It is, therefore, essential to consider the environmental impacts of concrete mix designs during the structural design of buildings in a more holistic way and include estimated impacts on energy performance during the operational phase and end of life (life cycle) of a building. Future research will quantify the potential effects of conventional and novel concrete materials on thermal performance of buildings. 


\section{Conclusion}

There are presently many efforts on compiling reliable methodologies for quantifying the environmental impacts of concrete production. Some of the available embodied emissions databases (eTool, Crawford, BPIC) propose an individual embodied $\mathrm{CO}_{2}$-e coefficient for each grade of concrete without considering variations across different mix designs. The findings from this study are consistent with the common literature and confirm that significant reductions in embodied $\mathrm{CO}_{2}$-e can be achieved by using supplementary cementitious materials such as fly ash, and GGBFS. Depending on the percentage of cement replacement, fly ash can typically contribute to reducing the embodied $\mathrm{CO}_{2}$-e of concrete by 10 to $15 \%$ when compared with Portland cement. GGBFS was also found to be capable of reducing concrete embodied $\mathrm{CO}_{2}$-e by $15.5 \%$ in comparison with common Portland cement. The embodied $\mathrm{CO}_{2}$-e analyses have shown variations across the different inventory databases. These recorded variations in embodied $\mathrm{CO}_{2}$-e are due to the different methods of analysis used in the different databases, the source of data and quality of input data (related to upstream process) in calculation. This highlights the need for transparency within existing and future databases and imposes a requirement for extending their capabilities to be able to model concrete mix design based on individual components.

When using the ICE database, the results for the embodied $\mathrm{CO}_{2}$-e were sensitive to the concrete mix design because the embodied $\mathrm{CO}_{2}$-e coefficients in ICE varied in accordance with the different percentages of cement, fly ash and GGBFS. From the analysis, it was shown that the embodied $\mathrm{CO}_{2}-\mathrm{e}$ of a mix design decreases by increasing the proportion of fly ash and GGBFS in the concrete binder. The slight limitation of the ICE database is that it does not take into account the effects of silica fume and cenosphere in concrete admixture mix, though these can be accounted for by including the cenosphere as additional fly ash and considering silica fume as a zero contribution.

The inventory databases from Crawford and eTool use the same embodied $\mathrm{CO}_{2}$-es coefficients for each grade of concrete without accounting for the effects of each different concrete component. The calculated embodied $\mathrm{CO}_{2}$-e from BPIC database which uses average industry values results in lower embodied $\mathrm{CO}_{2}$-e than those calculated with Crawford and eTool databases. 
However, the analysis based on the AusLCI, Alcorn's analysis and embodied $\mathrm{CO}_{2}$-e coefficients (Table

3) that were compiled for the purposes of this study considered the detailed effects of the materials in the concrete mix design. A considerable variation in embodied $\mathrm{CO}_{2}$-e of concrete mix designs was found. Meanwhile, there are some discrepancies between the results of this study and the AusLCI analysis. The discrepancies are due to differences in embodied $\mathrm{CO}_{2}$-e factor for Portland cement, fly ash, GGBFS and type of aggregates (recycled, natural and manufactured).

This study also demonstrates that the thermal conductivity of concrete is strongly related to the properties of the concrete mixes and the proportions of its constituents. In general, the thermal conductivity of a mix design increases with increasing density. The replacement of normal aggregates with lightweight aggregates significantly decreases the thermal conductivity of concrete. The lower density concrete mixes by having low thermal conductivity could be beneficial in terms of energy saving during the operational phase of buildings. On the other hand, it was found that lower density concrete mix designs could have high embodied $\mathrm{CO}_{2}$-e. Hence, it is crucial to understand and considered the thermal and environmental impacts associated with the concrete mix designs in an integrated way and at the design stage of building.

The results of this study can be used as guidance for considering reductions on the environmental impact and improving the thermal conductivity of concrete while maintaining the desired concrete strength during the early stages of building projects. Further studies will need to consider the potential impact of concrete mix design on specific heat and thermal mass and hence on the energy performance of a building over its operation phase and its entire life cycle. 


\section{References}

[1] G. Hammond, C. Jones, F. Lowrie, P. Tse, Embodied carbon: the inventory of carbon and energy (ICE), BSRIA, 2011.

[2] R. Crawford, Life cycle assessment in the built environment, Taylor \& Francis, 2011.

[3] A. Alcorn, Embodied Energy and CO2 Coefficients for NZ Building Materials, Centre for Building Performance Research, Wellington, 2003.

[4] eTool, Life Cycle Assessment Software in, 2014.

[5] BPIC, Building Product Life Cycle Inventory, Building Product Innovation council, 2014.

[6] AusLCI, The Australian National Life Cycle Inventory Database, in, 2016.

[7] ISO15673, Guidelines for the simplified design of structural reinforced concrete for buildings, The International Organization for Standardization, Switzerland, 2005.

[8] U.S.G. Survey, Mineral commodity summaries 2015, U.S. Geological Survey, Washington, 2015.

[9] PCA, Global Cement Consumption on the Rise, Portland Cement Association, 2015.

[10] F.P. Torgal, S. Jalali, Eco-efficient construction and building materials, London Limited: Springer Verlag, (2011).

[11] P. Appleby, Integrated sustainable design of buildings, Routledge, 2012.

[12] J.E. Anderson, R. Silman, A life cycle inventory of structural engineering design strategies for greenhouse gas reduction, Structural Engineering International, 19 (3) (2009) 283-288.

[13] L. Lemay, A. Leed, Life cycle assessment of concrete buildings, National Ready Mixed Concrete Association, CSR04 (2011 Oct), (2011).

[14] DIIS, Your home : Australia's guide to environmentally sustainable homes, Department of Industry, Innovation and Science, Canberra, 2013.

[15] ACI122R, Guide to Thermal Properties of Concrete and Masonry Systems, American Concrete Institute, 2014.

[16] CIBSE, Environmental design : CIBSE guide A, London, 2006.

[17] R. Kajaste, M. Hurme, Cement industry greenhouse gas emissions - management options and abatement cost, Journal of Cleaner Production, 112 (2016) 4041-4052.

[18] S.A. Ishak, H. Hashim, Low carbon measures for cement plant-a review, Journal of Cleaner Production, (2014).

[19] E. Worrell, C. Galitsky, L. Price, Energy efficiency improvement opportunities for the cement industry. Berkeley, CA: Lawrence Berkeley National Laboratory, in, Energy Analysis Department, California, 2008.

[20] B. McLellan, G. Corder, D. Giurco, K. Ishihara, Renewable energy in the minerals industry: a review of global potential, Journal of Cleaner Production, 32 (2012) 32-44.

[21] A. Rahman, M. Rasul, M.M.K. Khan, S. Sharma, Recent development on the uses of alternative fuels in cement manufacturing process, Fuel, 145 (2015) 84-99.

[22] P.C. Jacoby, F. Pelisser, Pozzolanic effect of porcelain polishing residue in Portland cement, Journal of Cleaner Production, 100 (2015) 84-88.

[23] S. de Castro, J. de Brito, Evaluation of the durability of concrete made with crushed glass aggregates, Journal of Cleaner Production, 41 (2013) 7-14.

[24] C. Ingrao, A.L. Giudice, C. Tricase, C. Mbohwa, R. Rana, The use of basalt aggregates in the production of concrete for the prefabrication industry: Environmental impact assessment, interpretation and improvement, Journal of Cleaner Production, 75 (2014) 195-204.

[25] P.K. Mehta, Greeningof the Concrete Industry for Sustainable Development, Concrete international, 23 (2002).

[26] D. Wimpenny, Low carbon concrete-options for the next generation of infrastructure, Concrete Solutions, 9 (2009) 41-41.

[27] M. Newlands, M. Jones, M. McCarthy, L. Zheng, Using fly ash to achieve low embodied CO2 concrete, in: Proceedings of EUROCOALASH 2012 Conference, 2012.

[28] M. Taylor, D. Collins, Novel Cements: Low energy, low carbon cements, Fact Sheet, 12 (2006).

[29] R. McLeod, Ordinary portland cement-with extraordinarily high CO2 emissions, BFF Autumn, (2005).

[30] P. Van den Heede, N. De Belie, Environmental impact and life cycle assessment (LCA) of traditional and 'green' concretes: Literature review and theoretical calculations, Cement and Concrete Composites, 34 (4) (2012) 431-442.

[31] R. Dhir, The potential of fly ash: the future looks bright, Concrete, 40 (6) (2006) 68-70.

[32] S. Wang, H. Wu, Environmental-benign utilisation of fly ash as low-cost adsorbents, Journal of Hazardous Materials, 136 (3) (2006) 482-501.

[33] AS3582.1, Supplementary cementitious materials - Fly ash, Standards Australia, Sydney, 2016.

[34] B. Marsh, High volume fly ash concrete, Concrete, 37 (4) (2003) 54-55.

[35] V. Malhotra, P. Mehta, High-performance, high-volume fly ash concrete, Concrete International, 24 (7) (2002) 30-34. 
[36] ADAA, Use of Fly Ash to Achieve Enhanced Sustainability in Green Star in: Fly Ash Technical Note No. 11, Ash Development Association of Australia, 2012.

[37] A.P. Gursel, H. Maryman, C. Ostertag, A life-cycle approach to environmental, mechanical, and durability properties of "green" concrete mixes with rice husk ash, Journal of Cleaner Production, 112 (2016) 823-836.

[38] G.N. Obuzor, J.M. Kinuthia, R.B. Robinson, Enhancing the durability of flooded low-capacity soils by utilizing lime-activated ground granulated blastfurnace slag (GGBS), Engineering Geology, 123 (3) (2011) 179 186.

[39] V.M. Malhotra, Reducing CO2 emissions, Concrete international, 28 (9) (2006) 42-45.

[40] S.J. Virgalitte, M.D. Luther, J.H. Rose, B. Mather, L.W. Bell, B.A. Ehmke, P. Klieger, D.M. Roy, B.M.

Call, R.D. Hooton, Ground Granulated Blast-Furnace Slag as a Cementitious Constituent in Concrete, American Concrete Institute ACI Report 233R-95, (1995).

[41] F. du béton, M. Glavind, Guidelines for green concrete structures: Guide to good practice, International Federation for Structural Concrete fib, 2011.

[42] D.M.A. Huiskes, A. Keulen, Q.L. Yu, H.J.H. Brouwers, Design and performance evaluation of ultralightweight geopolymer concrete, Materials \& Design, 89 (2016) 516-526.

[43] M.L. Berndt, J. Sanjayan, S. Foster, A. Castel, Pathways for overcoming barriers to implementation of low CO2 concrete, (2013).

[44] L.F. Cabeza, C. Barreneche, L. Miró, J.M. Morera, E. Bartolí, A. Inés Fernández, Low carbon and low embodied energy materials in buildings: A review, Renewable and Sustainable Energy Reviews, 23 (2013) 536542.

[45] J.S. Van Deventer, J.L. Provis, P. Duxson, Technical and commercial progress in the adoption of geopolymer cement, Minerals Engineering, 29 (2012) 89-104.

[46] P. Duxson, J.L. Provis, Low CO2 concrete: are we making any progress, BEDP environment design guide. Royal Australian Institute of Architects, Darwin, (2008).

[47] D. Gravitt, Eco-efficient Construction and Building Materials, Construction Management and Economics, 31 (11) (2013) 1164-1165.

[48] A. Rao, K.N. Jha, S. Misra, Use of aggregates from recycled construction and demolition waste in concrete, Resources, conservation and Recycling, 50 (1) (2007) 71-81.

[49] D.M. Flower, J. Sanjayan, Green house gas emissions due to concrete manufacture, The International Journal of Life Cycle Assessment, 12 (5) (2007) 282-288.

[50] K.R. O’Brien, J. Ménaché, L.M. O’Moore, Impact of fly ash content and fly ash transportation distance on embodied greenhouse gas emissions and water consumption in concrete, Int J Life Cycle Assess, 14 (7) (2009) 621-629.

[51] CCAA, Green Star Mat-4 Concrete Credit User Guide, Cement Concrete \& Aggregates Australia, (2015). [52] B. Zhang, C.S. Poon, Use of Furnace Bottom Ash for producing lightweight aggregate concrete with thermal insulation properties, Journal of Cleaner Production, 99 (2015) 94-100.

[53] M.L. Berndt, Influence of concrete mix design on $\mathrm{CO} 2$ emissions for large wind turbine foundations, Renewable Energy, 83 (2015) 608-614.

[54] Y. Wu, J.-Y. Wang, P.J.M. Monteiro, M.-H. Zhang, Development of ultra-lightweight cement composites with low thermal conductivity and high specific strength for energy efficient buildings, Construction and Building Materials, 87 (2015) 100-112.

[55] O. Damdelen, C. Georgopoulos, M. Limbachiya, Measuring Thermal Mass of Sustainable Concrete Mixes, Scholars' Press, 2015.

[56] T.S. Yun, Y.J. Jeong, T.-S. Han, K.-S. Youm, Evaluation of thermal conductivity for thermally insulated concretes, Energy and Buildings, 61 (2013) 125-132.

[57] S. Marinkovic, V. Radonjanin, M. Malesev, I. Ignjatovic, Comparative environmental assessment of natural and recycled aggregate concrete, Waste Manag, 30 (11) (2010) 2255-2264.

[58] N. Tošić, S. Marinković, T. Dašić, M. Stanić, Multicriteria optimization of natural and recycled aggregate concrete for structural use, Journal of Cleaner Production, 87 (2015) 766-776.

[59] L.M. O'Moore, K.R. O'Brien, Impact of supplementary cementitious material content and transportation distance on greenhouse gas emissions embodied in concrete, in: 24th Biennial Conference of Concrete Institute of Australia (Concrete 09), Concrete Institute of Australia, 2009, pp. 1-9.

[60] R. Rouwette, ACM - LCA of Geopolymer Concrete (E-Crete), (2012).

[61] J. McRobert, Sustainable aggregates - CO2 emission factor study, in: Jencie McRobert, ARRB Group, 2010.

[62] ADAA, Ash Development Association of Australian in, 2016.

[63] AGO, AGO factors and method workbook, Australian Greenhouse Office, Canberra, 2004.

[64] S. Chandra, L. Berntsson, Lightweight aggregate concrete, Elsevier, 2002.

[65] A.M. Neville, Properties of concrete, Prentice Hall, London; Marshfield, Mass., 2012.

[66] E. Gartner, Industrially interesting approaches to "low-CO 2" cements, Cement and Concrete research, 34

(9) (2004) 1489-1498. 
[67] J. Damtoft, J. Lukasik, D. Herfort, D. Sorrentino, E. Gartner, Sustainable development and climate change initiatives, Cement and concrete research, 38 (2) (2008) 115-127.

[68] E. Worrell, Energy efficiency improvement and cost saving opportunities for cement making. An Energy Star Guide for Energy and Plant Managers, Lawrence Berkeley National Laboratory, (2008).

[69] B. Whiting, T. McCarthy, E. Lume, Drying shrinkage of concrete made from recycled concrete aggregate, (2012).

[70] A.B. Srinivasreddy, T.J. McCarthy, E. Lume, Effect of rice husk ash on workability and strength of concrete, (2013).

[71] E. Crossin, Comparative Life Cycle Assessment of Concrete Blends, Centre for Design, RMIT University: Melbourne, Australia, (2012).

[72] M.K. Dixit, J.L. Fernández-Solís, S. Lavy, C.H. Culp, Identification of parameters for embodied energy measurement: A literature review, Energy and Buildings, 42 (8) (2010) 1238-1247.

[73] R.H. Crawford, Validation of a hybrid life-cycle inventory analysis method, Journal of environmental management, 88 (3) (2008) 496-506.

[74] L. Fan, J.M. Khodadadi, Thermal conductivity enhancement of phase change materials for thermal energy storage: A review, Renewable and Sustainable Energy Reviews, 15 (1) (2011) 24-46.

[75] D. Zhou, C.Y. Zhao, Y. Tian, Review on thermal energy storage with phase change materials (PCMs) in building applications, Applied Energy, 92 (2012) 593-605.

[76] H.K. Kim, J.H. Jeon, H.K. Lee, Workability, and mechanical, acoustic and thermal properties of lightweight aggregate concrete with a high volume of entrained air, Construction and Building Materials, 29 (2012) 193-200.

[77] S. Marinković, V. Radonjanin, M. Malešev, I. Ignjatović, Comparative environmental assessment of natural and recycled aggregate concrete, Waste Management, 30 (11) (2010) 2255-2264. 
Appendix 1- Mix properties of different batches of concrete

\begin{tabular}{|c|c|c|c|c|c|c|c|c|c|c|c|c|c|c|c|c|c|c|c|c|c|c|c|c|}
\hline \multirow[b]{2}{*}{ 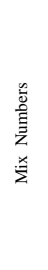 } & \multirow[b]{2}{*}{ 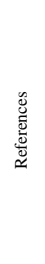 } & \multirow[b]{2}{*}{ 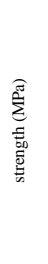 } & \multicolumn{6}{|c|}{ Binder $\left(\mathrm{kg} / \mathrm{m}^{3}\right)$} & \multicolumn{5}{|c|}{ Aggregates $\left(\mathbf{k g} / \mathbf{m}^{3}\right)$} & \multicolumn{6}{|c|}{ Admixture (liter) } & \multicolumn{2}{|c|}{ Water $\left(\mathrm{g} / \mathrm{m}^{3}\right)$} & & & \\
\hline & & & 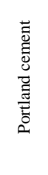 & $\begin{array}{l}\text { 剀 } \\
\text { 惫 }\end{array}$ & $\begin{array}{l}\text { 哥 } \\
\text { 童 }\end{array}$ & 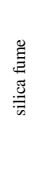 & 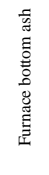 & 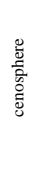 & 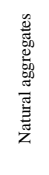 & 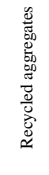 & 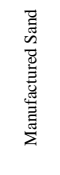 & 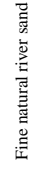 & 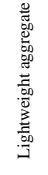 & 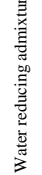 & 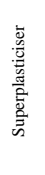 & 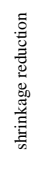 & 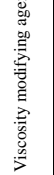 & 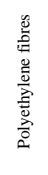 & 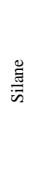 & 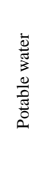 & 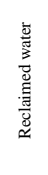 & 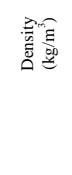 & 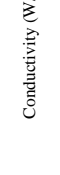 & 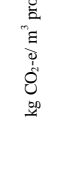 \\
\hline 1 & & 32 & 175 & 120 & 80 & $\ldots$ & $\ldots$ & $\ldots$ & 546 & 455 & 270 & 532 & $\ldots$ & 1.3 & $\ldots$ & $\ldots$ & $\ldots$ & $\ldots$ & $\ldots$ & $\ldots$ & 141 & 2320.3 & 1.84 & 200.9 \\
\hline 2 & $\overline{\underline{n}}$ & 32 & 255 & 85 & 35 & $\ldots$ & $\ldots$ & $\ldots$ & 549 & 445 & 245 & 589 & $\ldots$ & 1.3 & $\ldots$ & $\ldots$ & $\ldots$ & $\ldots$ & $\ldots$ & 68 & 70 & 2342.3 & 1.88 & 260.8 \\
\hline 3 & & 40 & 260 & 80 & 125 & $\ldots$ & $\ldots$ & $\ldots$ & 1067 & $\ldots$ & 90 & 580 & $\ldots$ & 1.6 & $\ldots$ & $\ldots$ & $\ldots$ & $\ldots$ & $\ldots$ & 76 & 70 & 2349.6 & 1.89 & 286.3 \\
\hline 4 & & 39.4 & 325 & $\ldots$ & $\cdots$ & $\ldots$ & $\ldots$ & $\ldots$ & 828 & $\ldots$ & 1041 & $\ldots$ & $\ldots$ & 3.6 & $\ldots$ & $\ldots$ & $\ldots$ & $\ldots$ & $\ldots$ & 195 & $\ldots$ & 2392.6 & 1.97 & 319.0 \\
\hline 5 & & 46.8 & 450 & $\ldots$ & $\ldots$ & $\ldots$ & $\ldots$ & $\ldots$ & $\ldots$ & $\ldots$ & 755 & $\ldots$ & 477 & 1.5 & $\ldots$ & $\ldots$ & $\ldots$ & $\ldots$ & $\ldots$ & 175 & $\ldots$ & 1858.5 & 1.35 & 401.4 \\
\hline 6 & $\overline{\widetilde{\pi}}$ & 42.7 & 450 & $\ldots$ & $\ldots$ & $\ldots$ & 156 & $\cdots$ & $\ldots$ & $\ldots$ & 566 & $\ldots$ & 477 & 2 & $\ldots$ & $\ldots$ & $\ldots$ & $\ldots$ & $\ldots$ & 175 & $\ldots$ & 1826.0 & 1.30 & 403.0 \\
\hline 7 & is & 40.9 & 450 & $\ldots$ & $\ldots$ & $\ldots$ & 312 & $\ldots$ & $\ldots$ & $\ldots$ & 377 & $\ldots$ & 477 & 1.4 & $\ldots$ & $\ldots$ & $\ldots$ & $\ldots$ & $\ldots$ & 175 & $\ldots$ & 1792.4 & 1.25 & 404.6 \\
\hline 8 & & 34.1 & 450 & $\ldots$ & $\ldots$ & $\ldots$ & 468 & $\ldots$ & $\ldots$ & $\ldots$ & 189 & $\ldots$ & 477 & 1.9 & $\ldots$ & $\ldots$ & $\ldots$ & $\ldots$ & $\ldots$ & 175 & $\ldots$ & 1760.9 & 1.20 & 406.2 \\
\hline 9 & & 31.6 & 450 & $\ldots$ & $\ldots$ & $\ldots$ & 624 & $\ldots$ & $\ldots$ & $\ldots$ & $\ldots$ & $\ldots$ & 477 & 1.8 & $\ldots$ & $\ldots$ & $\ldots$ & $\ldots$ & $\ldots$ & 175 & $\ldots$ & 1727.8 & 1.16 & 407.7 \\
\hline 10 & & 32 & 330 & $\ldots$ & $\cdots$ & $\ldots$ & $\ldots$ & $\ldots$ & 1093 & $\ldots$ & 778 & $\ldots$ & $\ldots$ & $\ldots$ & $\ldots$ & $\ldots$ & $\ldots$ & $\ldots$ & $\ldots$ & 160 & $\ldots$ & 2361.0 & 1.91 & 331.6 \\
\hline 11 & & 32 & 254 & $\ldots$ & 84.5 & $\ldots$ & $\ldots$ & $\ldots$ & 1090 & $\ldots$ & 787 & $\ldots$ & $\ldots$ & $\ldots$ & $\ldots$ & $\ldots$ & $\ldots$ & $\ldots$ & $\ldots$ & 170 & $\ldots$ & 2385.2 & 1.95 & 271.7 \\
\hline 12 & & 32 & 168 & $\ldots$ & $\ldots$ & $\ldots$ & $\ldots$ & $\ldots$ & 1089 & $\ldots$ & 774 & $\ldots$ & $\ldots$ & $\ldots$ & $\ldots$ & $\ldots$ & $\ldots$ & $\ldots$ & $\ldots$ & 164 & $\ldots$ & 2362.2 & 1.91 & 222.0 \\
\hline 13 & & 32 & 116 & $\ldots$ & $\ldots$ & $\ldots$ & $\ldots$ & $\ldots$ & 1095 & $\ldots$ & 780 & $\ldots$ & $\ldots$ & $\ldots$ & $\ldots$ & $\ldots$ & $\ldots$ & $\ldots$ & $\ldots$ & 159 & $\ldots$ & 2366.4 & 1.92 & 187.2 \\
\hline 14 & & 35 & 370 & $\ldots$ & $\ldots$ & $\ldots$ & $\ldots$ & $\ldots$ & 1035 & $\ldots$ & 801 & $\ldots$ & $\ldots$ & $\ldots$ & $\ldots$ & $\ldots$ & $\ldots$ & $\ldots$ & $\ldots$ & 157 & $\ldots$ & 2362.7 & 1.91 & 362.0 \\
\hline 15 & & 35 & 280 & $\ldots$ & 93 & $\ldots$ & $\ldots$ & $\ldots$ & 1054 & $\ldots$ & 797 & $\ldots$ & $\ldots$ & $\ldots$ & $\ldots$ & $\ldots$ & $\ldots$ & $\ldots$ & $\ldots$ & 158 & $\ldots$ & 2382.0 & 1.95 & 291.6 \\
\hline 16 & & 35 & 188 & $\ldots$ & $\ldots$ & $\ldots$ & $\ldots$ & $\ldots$ & 1039 & $\ldots$ & 784 & $\ldots$ & $\ldots$ & $\ldots$ & $\ldots$ & $\ldots$ & $\ldots$ & $\ldots$ & $\ldots$ & 158 & $\ldots$ & 2357.0 & 1.90 & 239.6 \\
\hline 17 & & 35 & 196 & $\ldots$ & $\ldots$ & $\ldots$ & $\ldots$ & $\ldots$ & $\ldots$ & 1053 & 743.4 & $\ldots$ & $\ldots$ & $\ldots$ & $\ldots$ & $\ldots$ & $\ldots$ & $\ldots$ & $\ldots$ & 157 & $\ldots$ & 2345.3 & 1.88 & 203.4 \\
\hline 18 & $\bar{\kappa}$ & 35 & 131 & $\ldots$ & $\ldots$ & $\ldots$ & $\ldots$ & $\ldots$ & 1061 & $\ldots$ & 780 & $\ldots$ & $\ldots$ & $\ldots$ & $\ldots$ & $\ldots$ & $\ldots$ & $\ldots$ & $\ldots$ & 158 & $\ldots$ & 2373.5 & 1.93 & 202.1 \\
\hline 19 & & 40 & 400 & $\ldots$ & $\ldots$ & $\ldots$ & $\ldots$ & $\ldots$ & 1080 & $\ldots$ & 710 & $\ldots$ & $\ldots$ & $\ldots$ & $\ldots$ & $\ldots$ & $\ldots$ & $\ldots$ & $\ldots$ & 168 & $\ldots$ & 2358.0 & 1.90 & 387.4 \\
\hline 20 & & 40 & 300 & $\ldots$ & 100 & $\ldots$ & $\ldots$ & $\ldots$ & 1095 & $\ldots$ & 719 & $\ldots$ & $\ldots$ & $\ldots$ & $\ldots$ & $\ldots$ & $\ldots$ & $\ldots$ & $\ldots$ & 164 & $\ldots$ & 2378.0 & $\begin{array}{ll}1.94 \\
\end{array}$ & 309.0 \\
\hline 21 & & 40 & 200 & $\ldots$ & $\ldots$ & $\ldots$ & $\ldots$ & $\ldots$ & 1082 & $\ldots$ & 715 & $\ldots$ & $\ldots$ & $\ldots$ & $\ldots$ & $\ldots$ & $\ldots$ & $\ldots$ & $\ldots$ & 166 & $\ldots$ & 2363.0 & 1.91 & 252.2 \\
\hline 22 & & 40 & 140 & $\ldots$ & $\cdots$ & $\ldots$ & $\ldots$ & $\ldots$ & 1075 & $\ldots$ & 712 & $\ldots$ & $\ldots$ & $\ldots$ & $\ldots$ & $\ldots$ & $\ldots$ & $\ldots$ & $\ldots$ & 167 & $\ldots$ & 2353.8 & 1.90 & 211.2 \\
\hline 23 & & 40 & 420 & $\ldots$ & $\ldots$ & $\ldots$ & $\ldots$ & $\ldots$ & 1030 & $\ldots$ & 715 & $\ldots$ & $\ldots$ & $\ldots$ & $\ldots$ & $\ldots$ & $\ldots$ & $\ldots$ & $\ldots$ & 168 & $\ldots$ & 2333.0 & 1.86 & 401.6 \\
\hline 24 & & 40 & 315 & $\ldots$ & 105 & $\ldots$ & $\ldots$ & $\ldots$ & 1020 & $\ldots$ & 718 & $\ldots$ & $\ldots$ & $\ldots$ & $\ldots$ & $\ldots$ & $\ldots$ & $\ldots$ & $\ldots$ & 172 & $\ldots$ & 2330.2 & 1.85 & 317.9 \\
\hline 25 & & 40 & 210 & $\ldots$ & $\ldots$ & $\ldots$ & $\ldots$ & $\ldots$ & 1040 & $\ldots$ & 740 & $\ldots$ & $\ldots$ & $\ldots$ & $\ldots$ & $\ldots$ & $\ldots$ & $\ldots$ & $\ldots$ & 164 & $\ldots$ & 2363.8 & 1.91 & 260.3 \\
\hline 26 & & 40 & 151 & $\ldots$ & $\ldots$ & $\ldots$ & $\ldots$ & $\ldots$ & 1048 & $\ldots$ & 720 & $\ldots$ & $\ldots$ & $\ldots$ & $\ldots$ & $\ldots$ & $\ldots$ & $\ldots$ & $\ldots$ & 168 & $\ldots$ & 2365.7 & 1.92 & 221.5 \\
\hline 27 & & 67.6 & 377 & $\ldots$ & $\ldots$ & 33 & $\ldots$ & $\ldots$ & 946 & $\ldots$ & 810 & $\ldots$ & $\ldots$ & $\ldots$ & 5.4 & $\ldots$ & $\ldots$ & $\ldots$ & $\ldots$ & 172 & $\ldots$ & 2343.4 & 1.98 & 364.9 \\
\hline 28 & & 69.4 & 836 & $\ldots$ & $\ldots$ & 73 & $\ldots$ & 348 & $\ldots$ & $\ldots$ & $\ldots$ & $\ldots$ & $\ldots$ & $\ldots$ & 4.9 & 10.5 & $\ldots$ & $\ldots$ & $\ldots$ & 302 & $\ldots$ & 1574.4 & 0.40 & 697.1 \\
\hline 29 & & 56.9 & 732 & $\ldots$ & $\ldots$ & 64 & $\ldots$ & 402 & $\ldots$ & $\ldots$ & $\ldots$ & $\ldots$ & $\ldots$ & $\ldots$ & 5.2 & 9.8 & $\ldots$ & $\ldots$ & $\ldots$ & 282 & $\ldots$ & 1495.0 & 0.36 & 613.1 \\
\hline 30 & & 55.9 & 731 & $\ldots$ & $\ldots$ & 64 & $\ldots$ & 268 & $\ldots$ & $\ldots$ & $\ldots$ & $\ldots$ & $\ldots$ & $\ldots$ & 5.9 & 8.9 & 0.2 & $\ldots$ & $\ldots$ & 287 & $\ldots$ & 1365.0 & 0.35 & 608.7 \\
\hline 31 & & 48.8 & 607 & $\ldots$ & $\ldots$ & 53 & $\ldots$ & 442 & $\ldots$ & $\ldots$ & $\ldots$ & $\ldots$ & $\ldots$ & $\ldots$ & 5.6 & 9.8 & $\ldots$ & $\ldots$ & $\ldots$ & 282 & $\ldots$ & 1399.4 & 0.33 & 511.3 \\
\hline 32 & & 33 & 499 & $\ldots$ & $\ldots$ & 43 & $\ldots$ & 317 & $\ldots$ & $\ldots$ & $\ldots$ & $\ldots$ & $\ldots$ & $\ldots$ & 6.6 & 9.1 & 0.2 & $\ldots$ & $\ldots$ & 290 & $\ldots$ & 1164.9 & 0.28 & 418.6 \\
\hline 33 & & 66.1 & 846 & $\ldots$ & $\ldots$ & 74 & $\ldots$ & 352 & $\ldots$ & $\ldots$ & $\ldots$ & $\ldots$ & $\ldots$ & $\ldots$ & 5.2 & $\ldots$ & $\ldots$ & $\ldots$ & $\ldots$ & 305 & $\ldots$ & 1582.2 & 0.39 & 705.6 \\
\hline 34 & F & 69.4 & 836 & $\ldots$ & $\ldots$ & 73 & $\ldots$ & 348 & $\ldots$ & $\ldots$ & $\ldots$ & $\ldots$ & $\ldots$ & $\ldots$ & 4.9 & 10.5 & $\ldots$ & $\ldots$ & $\ldots$ & 302 & $\ldots$ & 1574.4 & 0.40 & 697.1 \\
\hline 35 & & 49.8 & 607 & $\ldots$ & $\ldots$ & 53 & $\ldots$ & 442 & $\ldots$ & $\ldots$ & $\ldots$ & $\ldots$ & $\ldots$ & $\ldots$ & 5.6 & 9.8 & $\ldots$ & $\ldots$ & $\ldots$ & 282 & $\ldots$ & 1399.4 & 0.33 & 511.3 \\
\hline 36 & & 40.9 & 606 & $\ldots$ & $\ldots$ & 53 & $\ldots$ & 442 & $\ldots$ & $\ldots$ & $\ldots$ & $\ldots$ & $\ldots$ & $\ldots$ & 6.7 & 9.7 & 0.18 & $\ldots$ & $\ldots$ & 282 & $\ldots$ & 1399.6 & 0.31 & 510.5 \\
\hline 37 & & 66.1 & 846 & $\ldots$ & $\ldots$ & 74 & $\ldots$ & 352 & $\ldots$ & $\ldots$ & $\ldots$ & $\ldots$ & $\ldots$ & $\ldots$ & 5.2 & $\ldots$ & $\ldots$ & $\ldots$ & $\ldots$ & 305 & $\ldots$ & 1582.2 & 0.39 & 705.6 \\
\hline 38 & & 66.5 & 775 & $\ldots$ & $\ldots$ & 67 & $\ldots$ & 350 & $\ldots$ & $\ldots$ & $\ldots$ & $\ldots$ & $\ldots$ & $\ldots$ & 3.6 & $\ldots$ & $\ldots$ & 5.3 & 4.2 & 304 & $\ldots$ & 1509.1 & 0.43 & 646.5 \\
\hline 39 & & 54.4 & 832 & $\ldots$ & $\ldots$ & 72 & $\ldots$ & 346 & $\ldots$ & $\ldots$ & $\ldots$ & $\ldots$ & $\ldots$ & $\ldots$ & 4.3 & $\ldots$ & $\ldots$ & 5.7 & $\ldots$ & 301 & $\ldots$ & 1561.0 & 0.39 & 693.3 \\
\hline 40 & & 63.1 & 1355 & $\ldots$ & $\ldots$ & 118 & $\ldots$ & $\ldots$ & $\ldots$ & $\ldots$ & $\ldots$ & $\ldots$ & $\ldots$ & $\ldots$ & 1.3 & 14.9 & $\ldots$ & $\ldots$ & $\ldots$ & 499 & $\ldots$ & 1988.2 & 0.84 & 11144.4 \\
\hline 41 & & 51.3 & 1179 & $\ldots$ & $\ldots$ & 103 & $\ldots$ & $\ldots$ & $\ldots$ & $\ldots$ & $\ldots$ & $\ldots$ & $\ldots$ & $\ldots$ & $\ldots$ & 16.9 & 0.91 & $\ldots$ & $\ldots$ & 561 & $\ldots$ & 1860.8 & 0.80 & 969.9 \\
\hline 42 & & 45 & 345 & $\ldots$ & $\ldots$ & $\ldots$ & $\ldots$ & $\ldots$ & 1826 & $\ldots$ & $\ldots$ & $\ldots$ & $\ldots$ & $\ldots$ & $\ldots$ & $\ldots$ & $\ldots$ & $\ldots$ & $\ldots$ & 195 & $\ldots$ & 2366.0 & 0.92 & 366.7 \\
\hline 43 & & 42 & 190 & 155 & $\ldots$ & $\ldots$ & $\ldots$ & $\ldots$ & 1826 & $\ldots$ & $\ldots$ & $\ldots$ & $\ldots$ & $\ldots$ & $\ldots$ & $\ldots$ & $\ldots$ & $\ldots$ & $\ldots$ & 195 & $\ldots$ & 2366.0 & 0.88 & 261.8 \\
\hline 44 & & 41 & 295 & $\ldots$ & 60 & $\ldots$ & $\ldots$ & $\ldots$ & 1802 & $\ldots$ & $\ldots$ & $\ldots$ & $\ldots$ & $\ldots$ & $\ldots$ & $\ldots$ & $\ldots$ & $\ldots$ & $\ldots$ & 185 & $\ldots$ & 2342.0 & 0.82 & 326.2 \\
\hline 45 & & 43 & 275 & $\ldots$ & $\ldots$ & 70 & $\ldots$ & $\ldots$ & 1826 & $\ldots$ & $\ldots$ & $\ldots$ & $\ldots$ & $\ldots$ & $\ldots$ & $\ldots$ & $\ldots$ & $\ldots$ & $\ldots$ & 195 & $\ldots$ & 2366.0 & 0.84 & 311.2 \\
\hline 46 & & 39 & 345 & $\ldots$ & $\ldots$ & $\ldots$ & $\ldots$ & $\ldots$ & 1447 & $\ldots$ & $\ldots$ & $\ldots$ & $\ldots$ & $\ldots$ & $\ldots$ & $\ldots$ & $\ldots$ & $\ldots$ & $\ldots$ & 204 & $\ldots$ & 2361.0 & 0.72 & 350.8 \\
\hline 47 & & 42 & 190 & 155 & $\ldots$ & $\ldots$ & $\ldots$ & $\ldots$ & 1447 & $\ldots$ & $\ldots$ & $\ldots$ & $\ldots$ & $\ldots$ & $\ldots$ & $\ldots$ & $\ldots$ & $\ldots$ & $\ldots$ & 204 & $\ldots$ & 2361.0 & 0.67 & 245.8 \\
\hline 48 & $\sqrt{n}$ & 41 & 295 & $\ldots$ & 60 & $\ldots$ & $\ldots$ & $\ldots$ & 1438 & $\ldots$ & $\ldots$ & $\ldots$ & $\ldots$ & $\ldots$ & $\ldots$ & $\ldots$ & $\ldots$ & $\ldots$ & $\ldots$ & 189 & $\ldots$ & 2342.0 & 0.61 & 311.0 \\
\hline 49 & & 38 & 275 & $\ldots$ & $\ldots$ & 70 & $\ldots$ & $\ldots$ & 1447 & $\ldots$ & $\ldots$ & $\ldots$ & $\ldots$ & $\ldots$ & $\ldots$ & $\ldots$ & $\ldots$ & $\ldots$ & $\ldots$ & 204 & $\ldots$ & 2361.0 & 0.65 & 295.3 \\
\hline 50 & & 55 & 557 & $\ldots$ & $\ldots$ & $\ldots$ & $\ldots$ & $\ldots$ & 1610 & $\ldots$ & $\ldots$ & $\ldots$ & $\ldots$ & $\ldots$ & $\ldots$ & $\ldots$ & $\ldots$ & $\ldots$ & $\ldots$ & 195 & $\ldots$ & 2362.0 & 0.99 & 530.6 \\
\hline 51 & & 51 & 251 & 306 & $\ldots$ & $\ldots$ & $\ldots$ & $\ldots$ & 1610 & $\ldots$ & $\ldots$ & $\ldots$ & $\ldots$ & $\ldots$ & $\ldots$ & $\ldots$ & $\ldots$ & $\ldots$ & $\ldots$ & 195 & $\ldots$ & 2362.0 & 0.93 & 323.5 \\
\hline 52 & & 53 & 478 & $\ldots$ & 120 & $\ldots$ & $\ldots$ & $\ldots$ & 1583 & $\ldots$ & $\ldots$ & $\ldots$ & $\ldots$ & $\ldots$ & $\ldots$ & $\ldots$ & $\ldots$ & $\ldots$ & $\ldots$ & 180 & $\ldots$ & 2361.0 & $\begin{array}{l}0.89 \\
\end{array}$ & 467.9 \\
\hline 53 & & 54 & 501 & $\ldots$ & $\ldots$ & 111 & $\ldots$ & $\ldots$ & 1610 & $\ldots$ & $\ldots$ & $\ldots$ & $\ldots$ & $\ldots$ & $\ldots$ & $\ldots$ & $\ldots$ & $\ldots$ & $\ldots$ & 195 & $\ldots$ & 2417.0 & 0.90 & 487.7 \\
\hline 54 & & 54 & 583 & $\ldots$ & $\ldots$ & $\ldots$ & $\ldots$ & $\ldots$ & 1234 & $\ldots$ & $\ldots$ & $\ldots$ & $\ldots$ & $\ldots$ & $\ldots$ & $\ldots$ & $\ldots$ & $\ldots$ & $\ldots$ & 204 & $\ldots$ & 2358.0 & 0.77 & 536.0 \\
\hline 55 & & 49 & 321 & 262 & $\ldots$ & $\ldots$ & $\ldots$ & $\cdots$ & 1234 & 337 & $\ldots$ & $\ldots$ & $\ldots$ & $\ldots$ & $\ldots$ & $\ldots$ & $\ldots$ & $\ldots$ & $\ldots$ & 204 & $\cdots$ & 2358.0 & 0.73 & 358.7 \\
\hline 56 & & 48 & 502 & $\ldots$ & 126 & $\ldots$ & $\ldots$ & $\ldots$ & 1212 & 331 & $\ldots$ & $\ldots$ & $\ldots$ & $\ldots$ & $\ldots$ & $\ldots$ & $\ldots$ & $\ldots$ & $\ldots$ & 190 & $\ldots$ & 2361.0 & 0.70 & 472.0 \\
\hline 57 & & 52 & 466 & $\ldots$ & $\ldots$ & 117 & $\ldots$ & $\ldots$ & 1234 & 337 & $\ldots$ & $\ldots$ & $\ldots$ & $\ldots$ & $\ldots$ & $\ldots$ & $\ldots$ & $\ldots$ & $\ldots$ & 204 & $\ldots$ & 2358.0 & 0.75 & 443.3 \\
\hline
\end{tabular}




\begin{tabular}{|c|c|c|c|c|c|c|c|c|c|c|c|c|c|c|c|c|c|c|c|c|c|c|c|c|}
\hline 58 & \multirow{12}{*}{ 它 } & 43.9 & 288 & $\ldots$ & 32 & $\ldots$ & $\ldots$ & $\ldots$ & 1756 & $\ldots$ & $\ldots$ & $\ldots$ & $\ldots$ & $\ldots$ & $\ldots$ & $\ldots$ & $\ldots$ & $\ldots$ & $\ldots$ & 175 & $\ldots$ & 2251.0 & 1.93 & 317.6 \\
\hline 59 & & NA & 288 & $\ldots$ & 32 & $\ldots$ & $\ldots$ & 6 & 1730 & $\ldots$ & $\ldots$ & $\ldots$ & $\ldots$ & $\ldots$ & $\ldots$ & $\ldots$ & $\ldots$ & $\ldots$ & $\ldots$ & 175 & $\ldots$ & 2231.0 & 1.67 & 316.6 \\
\hline 60 & & 35.3 & 288 & $\ldots$ & 32 & $\ldots$ & $\ldots$ & 12 & 1602 & $\ldots$ & $\ldots$ & $\ldots$ & $\ldots$ & $\ldots$ & $\ldots$ & $\ldots$ & $\ldots$ & $\ldots$ & $\ldots$ & 175 & $\ldots$ & 2109.0 & 1.71 & 310.9 \\
\hline 61 & & 32.1 & 288 & $\ldots$ & 32 & $\ldots$ & $\ldots$ & 24 & 1364 & $\ldots$ & $\ldots$ & $\ldots$ & $\ldots$ & $\ldots$ & $\ldots$ & $\ldots$ & $\ldots$ & $\ldots$ & $\ldots$ & 175 & $\ldots$ & 1883.0 & 1.56 & 300.3 \\
\hline 62 & & 24.6 & 288 & $\ldots$ & 32 & $\ldots$ & $\ldots$ & 37 & 1097 & $\ldots$ & $\ldots$ & $\ldots$ & $\ldots$ & $\ldots$ & $\ldots$ & $\ldots$ & $\ldots$ & $\ldots$ & $\ldots$ & 175 & $\ldots$ & 1629.0 & 1.44 & 288.4 \\
\hline 63 & & 37.5 & 288 & $\ldots$ & 32 & $\ldots$ & $\ldots$ & $\ldots$ & 826 & $\ldots$ & $\ldots$ & $\ldots$ & 552 & $\ldots$ & $\ldots$ & $\ldots$ & $\ldots$ & $\ldots$ & $\ldots$ & 175 & $\ldots$ & 1873.0 & 1.32 & 300.3 \\
\hline 64 & & 36.2 & 288 & $\ldots$ & 32 & $\ldots$ & $\ldots$ & 12 & 826 & $\ldots$ & $\ldots$ & $\ldots$ & 409 & $\ldots$ & $\ldots$ & $\ldots$ & $\ldots$ & $\ldots$ & $\ldots$ & 175 & $\ldots$ & 1742.0 & 1.28 & 294.0 \\
\hline 65 & & 28.1 & 288 & $\ldots$ & 32 & $\ldots$ & $\ldots$ & 23 & 826 & $\ldots$ & $\ldots$ & $\ldots$ & 276 & $\ldots$ & $\ldots$ & $\ldots$ & $\ldots$ & $\ldots$ & $\ldots$ & 175 & $\ldots$ & 1620.0 & 1.25 & 288.2 \\
\hline 66 & & 23 & 288 & $\ldots$ & 32 & $\ldots$ & $\ldots$ & 35 & 826 & $\ldots$ & $\ldots$ & $\ldots$ & 127 & $\ldots$ & $\ldots$ & $\ldots$ & $\ldots$ & $\ldots$ & $\ldots$ & 175 & $\ldots$ & 1483.0 & 1.18 & 281.7 \\
\hline 67 & & 37.7 & 288 & $\ldots$ & 32 & $\ldots$ & $\ldots$ & $\ldots$ & 834 & $\ldots$ & $\ldots$ & $\ldots$ & 583 & $\ldots$ & $\ldots$ & $\ldots$ & $\ldots$ & $\ldots$ & $\ldots$ & 175 & $\ldots$ & 1912.0 & 1.33 & 302.1 \\
\hline 68 & & 33 & 288 & $\ldots$ & 32 & $\ldots$ & $\ldots$ & 23 & 826 & $\ldots$ & $\ldots$ & $\ldots$ & 289 & $\ldots$ & $\ldots$ & $\ldots$ & $\ldots$ & $\ldots$ & $\ldots$ & 175 & $\ldots$ & 1633.0 & 1.30 & 288.8 \\
\hline 69 & & 36 & 288 & $\ldots$ & 32 & $\ldots$ & $\ldots$ & $\ldots$ & 834 & $\ldots$ & $\ldots$ & $\ldots$ & 510 & $\ldots$ & $\ldots$ & $\ldots$ & $\ldots$ & $\ldots$ & $\ldots$ & 175 & $\ldots$ & 1839.0 & 1.29 & 298.7 \\
\hline 70 & \multirow{6}{*}{$E$} & 36.6 & 300 & $\ldots$ & $\ldots$ & $\ldots$ & $\ldots$ & $\ldots$ & 1902 & $\ldots$ & $\ldots$ & $\ldots$ & $\ldots$ & $\ldots$ & $\ldots$ & $\ldots$ & $\ldots$ & $\ldots$ & $\ldots$ & 179 & $\ldots$ & 2381.0 & 1.95 & 333.3 \\
\hline 71 & & 41.8 & 353 & $\ldots$ & $\ldots$ & $\ldots$ & $\ldots$ & $\ldots$ & 1854 & $\ldots$ & $\ldots$ & $\ldots$ & $\ldots$ & $\ldots$ & $\ldots$ & $\ldots$ & $\ldots$ & $\ldots$ & $\ldots$ & 182 & $\ldots$ & 2389.0 & 1.96 & 374.6 \\
\hline 72 & & 48.6 & 402 & & $\ldots$ & $\ldots$ & & & 1798 & $\ldots$ & $\ldots$ & $\ldots$ & $\ldots$ & $\ldots$ & $\ldots$ & $\ldots$ & $\ldots$ & & $\ldots$ & 188 & $\ldots$ & 2388.0 & 1.96 & 412.2 \\
\hline 73 & & 33.6 & 300 & $\ldots$ & $\ldots$ & $\ldots$ & $\ldots$ & $\ldots$ & 611 & $\ldots$ & $\ldots$ & $\ldots$ & $\ldots$ & $\ldots$ & $\ldots$ & $\ldots$ & $\ldots$ & $\ldots$ & $\ldots$ & 179 & 40 & 1130.0 & 1.73 & 274.0 \\
\hline 74 & & 41.1 & 351 & $\ldots$ & $\ldots$ & $\ldots$ & $\ldots$ & $\ldots$ & 596 & $\ldots$ & $\ldots$ & $\ldots$ & $\ldots$ & $\ldots$ & $\ldots$ & $\ldots$ & $\ldots$ & $\ldots$ & $\ldots$ & 183 & 39 & 1169.0 & 1.76 & 315.2 \\
\hline 75 & & 48.1 & 402 & $\ldots$ & $\ldots$ & $\ldots$ & $\ldots$ & $\ldots$ & 579 & $\ldots$ & $\ldots$ & $\ldots$ & $\ldots$ & $\ldots$ & $\ldots$ & $\ldots$ & $\ldots$ & $\ldots$ & $\ldots$ & 189 & 29 & 1199.0 & 1.75 & 356.2 \\
\hline 76 & \multirow{4}{*}{ 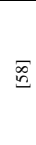 } & 43.7 & 354 & $\ldots$ & $\ldots$ & $\ldots$ & $\ldots$ & $\ldots$ & 1164 & $\ldots$ & $\ldots$ & $\ldots$ & $\ldots$ & $\ldots$ & $\ldots$ & $\ldots$ & $\ldots$ & $\ldots$ & $\ldots$ & 185 & $\ldots$ & 1703.0 & 1.98 & 343.7 \\
\hline 77 & & 41.5 & 384 & $\ldots$ & $\ldots$ & $\ldots$ & $\ldots$ & $\ldots$ & 1165 & $\ldots$ & $\ldots$ & $\ldots$ & $\ldots$ & $\ldots$ & $\ldots$ & $\ldots$ & $\ldots$ & $\ldots$ & $\ldots$ & 201 & $\ldots$ & 1750.0 & 1.90 & 368.4 \\
\hline 78 & & 44.2 & 354 & $\ldots$ & $\ldots$ & $\ldots$ & $\ldots$ & $\ldots$ & 555 & 555 & $\ldots$ & $\ldots$ & $\ldots$ & $\ldots$ & $\ldots$ & $\ldots$ & $\ldots$ & $\ldots$ & $\ldots$ & 185 & 20 & 1669.0 & 1.87 & 318.0 \\
\hline 79 & & 42.5 & 365 & $\ldots$ & $\ldots$ & $\ldots$ & $\ldots$ & $\ldots$ & $\ldots$ & 1071 & $\ldots$ & $\ldots$ & $\ldots$ & $\ldots$ & $\ldots$ & $\ldots$ & $\ldots$ & $\ldots$ & $\ldots$ & 180 & 38 & 1654.0 & 1.82 & 303.6 \\
\hline 80 & \multirow{11}{*}{$\overline{\widehat{\sigma}}$} & 32 & 324 & $\ldots$ & $\ldots$ & $\ldots$ & $\ldots$ & $\ldots$ & 1929 & $\ldots$ & $\ldots$ & $\ldots$ & $\ldots$ & $\ldots$ & $\ldots$ & $\ldots$ & $\ldots$ & $\ldots$ & $\ldots$ & 184 & $\ldots$ & 2437.0 & 2.05 & 354.2 \\
\hline 81 & & 32 & 273 & $\ldots$ & 510 & $\ldots$ & $\ldots$ & $\ldots$ & 1931 & $\ldots$ & $\ldots$ & $\ldots$ & $\ldots$ & $\ldots$ & $\ldots$ & $\ldots$ & $\ldots$ & $\ldots$ & $\ldots$ & 181 & $\ldots$ & 2895.0 & 2.88 & 326.3 \\
\hline 82 & & 32 & 258 & $\ldots$ & 660 & $\ldots$ & $\ldots$ & $\ldots$ & 1921 & $\ldots$ & $\ldots$ & $\ldots$ & $\ldots$ & $\ldots$ & $\ldots$ & $\ldots$ & $\ldots$ & $\ldots$ & $\ldots$ & 183 & $\ldots$ & 3022.1 & 3.11 & 317.6 \\
\hline 83 & & 32 & 243 & $\ldots$ & 81 & $\ldots$ & $\ldots$ & $\ldots$ & 1923 & $\ldots$ & $\ldots$ & $\ldots$ & $\ldots$ & $\ldots$ & $\ldots$ & $\ldots$ & $\ldots$ & $\ldots$ & $\ldots$ & 180 & $\ldots$ & 2427.0 & 2.03 & 289.7 \\
\hline 84 & & 32 & 227 & $\ldots$ & 96 & $\ldots$ & $\ldots$ & $\ldots$ & 1924 & $\ldots$ & $\ldots$ & $\ldots$ & $\ldots$ & $\ldots$ & $\ldots$ & $\ldots$ & $\ldots$ & $\ldots$ & $\ldots$ & 185 & $\ldots$ & 2432.0 & 2.04 & 277.0 \\
\hline 85 & & 32 & 192 & $\ldots$ & 128 & $\ldots$ & $\ldots$ & $\ldots$ & 1910 & $\ldots$ & $\ldots$ & $\ldots$ & $\ldots$ & $\ldots$ & $\ldots$ & $\ldots$ & $\ldots$ & $\ldots$ & $\ldots$ & 177 & $\ldots$ & 2407.0 & 1.99 & 248.6 \\
\hline 86 & & 32 & 240 & 80 & $\ldots$ & $\ldots$ & $\ldots$ & $\ldots$ & 1910 & $\ldots$ & $\ldots$ & $\ldots$ & $\ldots$ & $\ldots$ & $\ldots$ & $\ldots$ & $\ldots$ & $\ldots$ & $\ldots$ & 240 & $\ldots$ & 2470.0 & 2.11 & 295.9 \\
\hline 87 & & 32 & 220 & 100 & $\ldots$ & $\ldots$ & $\ldots$ & $\ldots$ & 1910 & $\ldots$ & $\ldots$ & $\ldots$ & $\ldots$ & $\ldots$ & $\ldots$ & $\ldots$ & $\ldots$ & $\ldots$ & $\ldots$ & 220 & $\ldots$ & 2450.0 & 2.07 & 282.4 \\
\hline 88 & & 32 & 210 & 110 & $\ldots$ & $\ldots$ & $\ldots$ & $\ldots$ & 1910 & $\ldots$ & $\ldots$ & $\ldots$ & $\ldots$ & $\ldots$ & $\ldots$ & $\ldots$ & $\ldots$ & $\ldots$ & $\ldots$ & 210 & $\ldots$ & 2440.0 & 2.05 & 275.6 \\
\hline 89 & & 32 & 190 & 130 & $\ldots$ & $\ldots$ & $\ldots$ & $\ldots$ & 1910 & $\ldots$ & $\ldots$ & $\ldots$ & $\ldots$ & $\ldots$ & $\ldots$ & $\ldots$ & $\ldots$ & $\ldots$ & $\ldots$ & 190 & $\ldots$ & 2420.0 & 2.02 & 262.1 \\
\hline 90 & & 32 & 180 & 100 & $\ldots$ & $\ldots$ & $\ldots$ & $\ldots$ & 1910 & $\ldots$ & $\ldots$ & $\ldots$ & & & $\ldots$ & & $\ldots$ & & & 180 & $\ldots$ & 2370.0 & 1.93 & 249.6 \\
\hline
\end{tabular}

